\title{
1-1/2-LOOP SEMISCALE ISOTHERMAL TEST PROGRAM- PROGRAM AND SYSTEM DESCRIPTION IN SUPPORT OF EXPERIMENT DATA REPORTS
}
S. A. Naff
P. A. Pinson

\section{Aerojet nuclear Company NATIONAL REACTOR TESTING STATION Idaho Falls, Idaho -83401}

\section{MASTER}

DATE PUBLISHED-FEBRUARY 1974

PREPARED FOR THE

\section{U. S. ATOMIC ENERGY COMMISSION}

IDAHO OPERATIONS OFFICE UNDER CONTRACT AT(10-1)-1375 


\section{DISCLAIMER}

This report was prepared as an account of work sponsored by an agency of the United States Government. Neither the United States Government nor any agency Thereof, nor any of their employees, makes any warranty, express or implied, or assumes any legal liability or responsibility for the accuracy, completeness, or usefulness of any information, apparatus, product, or process disclosed, or represents that its use would not infringe privately owned rights. Reference herein to any specific commercial product, process, or service by trade name, trademark, manufacturer, or otherwise does not necessarily constitute or imply its endorsement, recommendation, or favoring by the United States Government or any agency thereof. The views and opinions of authors expressed herein do not necessarily state or reflect those of the United States Government or any agency thereof. 


\section{DISCLAIMER}

Portions of this document may be illegible in electronic image products. Images are produced from the best available original document. 


\section{DISCLAIMER}

This report was prepared as an account of work sponsored by an agency of the United States Government. Neither the United States Government nor any agency Thereof, nor any of their employees, makes any warranty, express or implied, or assumes any legal liability or responsibility for the accuracy, completeness, or usefulness of any information, apparatus, product, or process disclosed, or represents that its use would not infringe privately owned rights. Reference herein to any specific commercial product, process, or service by trade name, trademark, manufacturer, or otherwise does not necessarily constitute or imply its endorsement, recommendation, or favoring by the United States Government or any agency thereof. The views and opinions of authors expressed herein do not necessarily state or reflect those of the United States Government or any agency thereof. 


\section{DISCLAIMER}

Portions of this document may be illegible in electronic image products. Images are produced from the best available original document. 
Printed in the United States of America
Available from

National Technical Information Service

U. S. Department of Commerce

S285 Port Royal Road

Springfield, Virginia 22151

Price: Printed Copy $\$ 5.45$; Microfiche $\$ 0.95$

\section{LEGAL NOTICE}

This report was prepared as an account of work sponsored by the United States Government. Neither the United States nor the United States Atomic Energy Commission, nor any of their emplayees, nor any of their contractors, subcontractors, or their employees, makes any warranty, express or implied, or assumes any legal liability or responsibility for the accuracy, completeness or usefulness of any information, apparatus, product or process dis-

closed, or represents that its use would not infringe privately owned rights. 


\section{1-1/2-LOOP SEMISCALE ISOTHERMAL TEST PROGRAM .. PROGR AM}

\section{AND SYSTEM DESCRIPTION IN SUPPORT OF}

\section{EXPERIMENT DATA REPORTS}

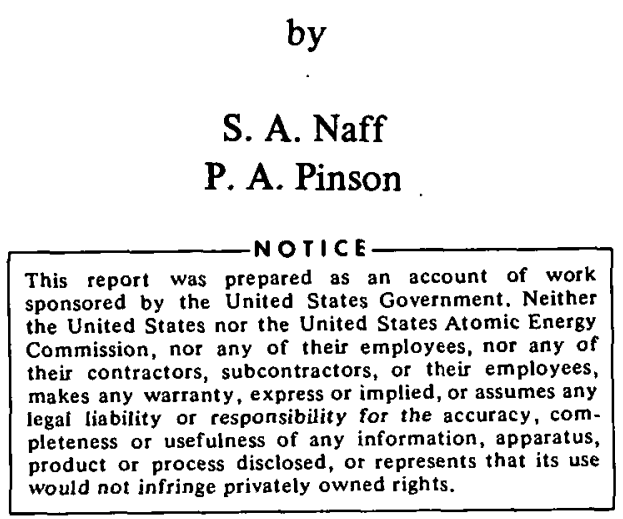

AEROJET NUCLEAR COMPANY

Date Published - February 1974

\section{PREPARED FOR THE U. S. ATOMIC ENERGY COMMISSION \\ IDAHO OPERATIONS OFFICE \\ UNDER CONTRACT NO. AT(10-1)-1375




\begin{abstract}
The isothermal test series is part of the Semiscale Blowdown and Emergency Core Cooling (ECC) Project conducted by Aerojet Nuclear Company for the U. S. Atomic Energy Commission. The test series consisted of ten blowdown tests and five hot-wall tests with emphasis on emergency core coolant delivery. The blowdown tests were conducted to investigate the effects of lower plenum geometry, heat transfer configuration, ECC injection location, downcomer gap size, and break size. The hot-wall tests were conducted to investigate the effects of residual vessel wall heat on ECC delivery after blowdown was completed.
\end{abstract}

The test system included a pressure vessel with internals; an operating loop with steam generator, pump, and pressurizer; a.blowdown loop with rupture assembly, simulated pump, and simulated steam generator; a pressure suppression system with suppression tank and header, and a simulated ECC system with accumulators and injection pumps.

The isothermal test program, 1-1/2-loop semiscale system, experimental instrumentation, operating procedures, and test conditions are described in this report to provide a reference document for support of the data reports specific to one or more of the isothermal tests. 
ABSTRACT $\ldots \ldots \ldots \ldots \ldots \ldots \ldots \ldots \ldots$ ii

I. INTRODUCTION $\ldots \ldots \ldots \ldots \ldots \ldots \ldots \ldots \ldots \ldots \ldots$

II. ISOTHERMAL BLOWDOWN PROGRAM DESCRIPTION $\ldots \ldots \ldots \ldots$

1. BLOWDOWN TESTS $\ldots \ldots \ldots \ldots \ldots \ldots \ldots$

2. HOT-WALL TESTS $\ldots \ldots \ldots \ldots \ldots \ldots$

III. TEST APPARATUS $\ldots \ldots \ldots \ldots \ldots \ldots \ldots \ldots$

1. PRESSURE VESSEL AND INTERNALS $\ldots \ldots \ldots \ldots \ldots$

2. OPERATING LOOP $\ldots \ldots \ldots \ldots \ldots \ldots \ldots \ldots \ldots \ldots \ldots$

2.1 Operating Loop Piping $\ldots \ldots \ldots \ldots \ldots$

2.2 Steam Generator $\ldots \ldots \ldots \ldots \ldots$

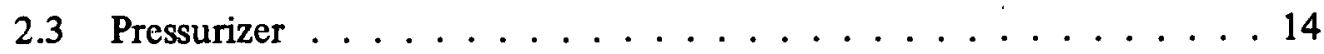

2.4 Circulating Pump $\ldots \ldots \ldots \ldots \ldots \ldots$

3. BLOWDOWN LOOP $\ldots \ldots \ldots \ldots \ldots \ldots \ldots \ldots \ldots \ldots \ldots \ldots$

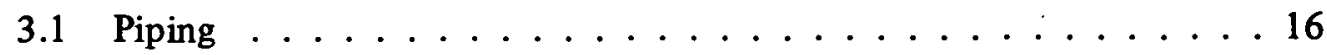

3.2 Simulated Steam Generator and Simulated Pump . . . . . . . . 17

3.3 Rupture Assemblies . . . . . . . . . . . . . . . . 17

4. PRESSURE SUPPRESSION SYSTEM $\ldots \ldots \ldots \ldots \ldots \ldots \ldots$

4.1 Pressure Suppression Tank $\ldots \ldots \ldots \ldots \ldots \ldots$

4.2 Pressure Suppression Header $\ldots \ldots \ldots \ldots \ldots \ldots$

5. ECC INJECTION SYSTEM $\ldots \ldots \ldots \ldots \ldots \ldots \ldots \ldots \ldots$

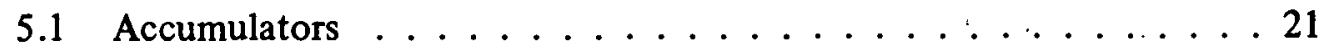

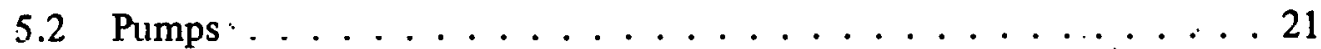

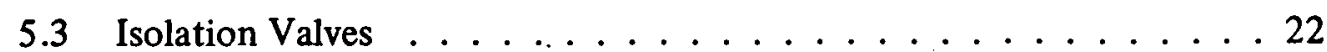

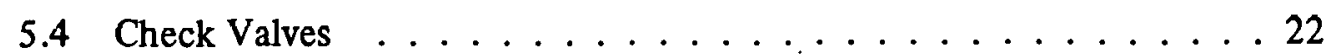


IV. INSTRUMENTATION $\ldots \ldots \ldots \ldots \ldots \ldots \ldots \ldots \ldots \ldots \ldots$

1. INSTRUMENT SYSTEM CONFIGURATION $\ldots \ldots \ldots \ldots \ldots$

V. OPERATING PROCEDURES AND TEST CONDITIONS $\ldots \ldots \ldots \ldots$

1. PRIMARY SYSTEM HEATUP AND PRESSURIZATION $\ldots \ldots \ldots$

2. TESTING SEQUENCE $\ldots \ldots \ldots \ldots \ldots \ldots \ldots \ldots$

VI. METHODS USED TO OBTAIN TEST DATA FROM INSTRUMENT OUTPUT . . 42

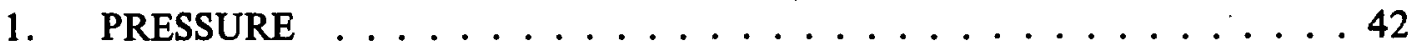

2. DIFFERENTIAL PRESSURE $\ldots \ldots \ldots \ldots \ldots \ldots \ldots \ldots$

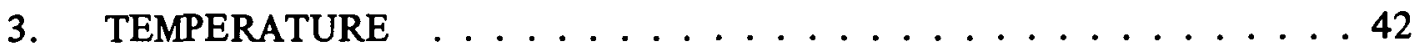

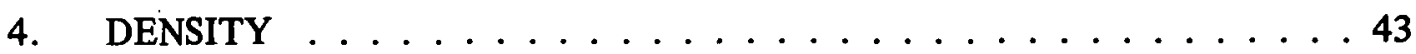

5. VOLUMETRIC FLOW RATE . . . . . . . . . . . . 43

6. VELOCITY $\ldots \ldots \ldots \ldots \ldots \ldots \ldots \ldots \ldots \ldots \ldots \ldots \ldots$

7. MOMENTUM FLUX $\ldots \ldots \ldots \ldots \ldots \ldots \ldots \ldots \ldots$

8. MASS FLOW RATE $\ldots \ldots \ldots \ldots \ldots \ldots \ldots \ldots \ldots$

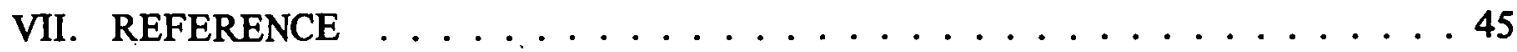

\section{FIGURES}

1. 1-1/2-1oop semiscale system - isometric $\ldots \ldots \ldots \ldots \ldots \ldots$

2. 1-1/2-1oop semiscale system -piping schematic $\ldots \ldots \ldots \ldots \ldots$

3. Pressure vessel, cross-sectional view $\ldots \ldots \ldots \ldots \ldots \ldots \ldots \ldots \ldots \ldots$

4. Steam generator, cross-sectional view $\ldots \ldots \ldots \ldots \ldots \ldots$

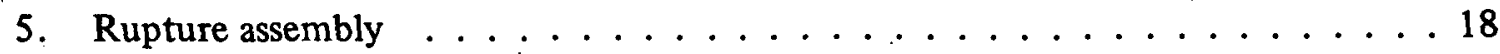

6. Hot leg break nozzle assembly . . . . . . . . . . . . . . . . . . 19

7. Cold leg break nozzle assembly $\ldots \ldots \ldots \ldots \ldots \ldots \ldots \ldots \ldots \ldots \ldots$

8. Instrumentation system schematic $\ldots \ldots \ldots \ldots \ldots \ldots \ldots$ 
9. $1-1 / 2-$ loop semiscale system - instrumentation isometric $\ldots \ldots . \ldots 27$

10. $1-1 / 2$-loop semiscale system - instrumentation schematic $\ldots \ldots . \ldots$

11. Pressure vessel with instrumentation, cross-sectional view . . . . . . . . . 29

12. Pressure vessel with instrumentation - isometric . . . . . . . . . . 30

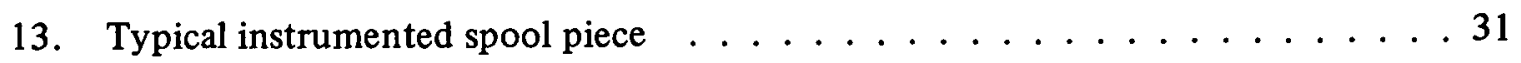

\section{TABLES}

I. Summary of Semiscale Isothermal Tests ............... 4

II. Liquid Volume Distribution for $1-1 / 2$-Loop Isothermal System . . . . . . . . 10

III. Measured System Pressure Drops and Calculated Flow Resistances . . . . . . . 11

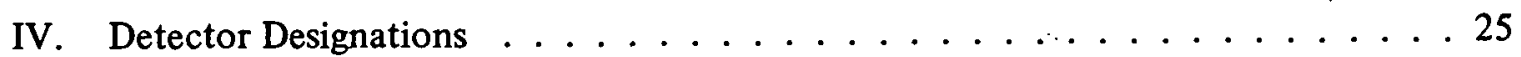

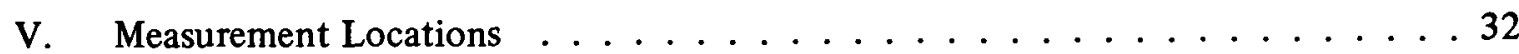

VI. Detector Characteristics and Measurement System Maximum Error . . . . . . . 39 


\title{
1-1/2-LOOP SEMISCALE ISOTHERMAL TEST PROGRAM -. PROG RAM
}

\section{AND SYSTEM DESCRIPTION IN SUPPORT OF}

\author{
EXPERIMENT DATA REPORTS
}

\section{INTRODUCTION}

The isothermal test program is part of the Semiscale Blowdown and Emergency Core Cooling (ECC) Project conducted by Aerojet Nuclear Company in the overall AEC-sponsored research and development program directed at quantifying loss-of-coolant accident (LOCA) behavior of a pressurized water reactor. The emphasis in the isothermal test program is on ECC delivery investigations.

The 1-1/2-loop semiscale system in which the isothermal test program was performed represents a new configuration for blowdown experiments in that both an intact operating loop and a broken loop are simulated. Prior to this program, the primary source of coupled-system response data was the single-loop semiscale blowdown tests ${ }^{[1]}$. Although the single-loop tests provided valuable results for evaluating the capability of analytical models for handling the decompression in a simplified blowdown experiment, the tests were not intended to provide representative data for multiple-loop systems having strong coupling between loop hydraulic behavior, pump performance, and energy transfer processes. The 1-1/2-loop system configuration, however, was designed to provide a source of coupledsystem response data from which to obtain a more comprehensive understanding of the thermal-hydraulic processes accompanying the major transient phases of an LOCA.

The operating loop in the 1-1/2-loop configuration represents three operating loops of a pressurized water reactor (PWR), and the blowdown loop with simulated pump and steam generator represents the broken loop of a PWR. A pressure suppression system including a tank and a header simulates backpressure of a containment building. The 1-1/2-loop configuration and programs, like other semiscale systems and programs, are directly related to PWR and Loss-of-Fluid Test (LOFT) safety studies. The semiscale program is closely related to the LOFT program because the semiscale and LOFT programs are the principal experimental activities that produce system coupled-response data for testing current analy tical capabilities over all phases of an LOCA. However, the relationship between LOFT and semiscale extends beyond that of two programs contributing to a common data base for model assessment and verification. The scale ratio between semiscale and LOFT ( 1:50) is nearly the same as that between LOFT and a PWR; therefore, the semiscale system provides a means for assessing the scaling relationships involved in interpreting LOFT experimental results in terms of PWR response and in applying analysis techniques to the larger pressurized water reactor systems.

The results of the tests in the isothermal program are expected to provide the following: (a) a significant contribution to the existing coupled-effects data base for 
dévelopment and evaluation of LOCA analytical methods, (b) a basis for determining the applicability of the steady state countercurrent flow results obtained from separate-effects tests in the semiscale program (transparent vessel tests and steady state tests) for predicting blowdown behavior, and (c) a data base, including both separate-effects and coupled-effects results for countercurrent flow, for use with data from larger scale separate effects experiments (AEC-industry cooperative programs) to establish the effect of physical scaling.

The purpose of this report is to provide a reference source of information for support of data reports relating to specific isothermal tests.

Presented are descriptions of the test program, test apparatus, instrumentation, operating procedures, and test conditions. 


\section{ISOTHERMAL BLOWDOWN PROGRAM DESCRIPTION}

The isothermal blowdown tests investigated the response of a simulated reactor system to a sudden decompression and subsequent injection of ECC coolant. Primary emphasis was placed on determining the coupled response of the system to variations in the following:

(1) ECC injection location

(2) Downcomer gap size

(3) Lower plenum geometry

(4) Heat transfer configuration

(5) Break nozzle configuration.

In each test, the isothermal system was heated to about $575^{\circ} \mathrm{F}$, pressurized to about 2250 psig, and subjected to a controlled double-ended break in the cold leg of the blowdown loop. Test data were collected during system decompression. The differences in test hardware configurations provided the means for varying system response during the decompression. In some cases, after blowdown was completed, data were taken with ECC injection continuing until the lower plenum was filled. This postblowdown portion of testing, designated hot-wall testing, was conducted to determine the effects of stored wall heat on ECC delivery. Table I summarizes the isothermal test configurations, and the following paragraphs briefly discuss each test.

\section{BLOWDOWN TESTS}

(a) Test 1001 . Test 1001 was conducted to determine the system reference hydraulic behavior during sudden decompression. The pressure vessel was equipped with the standard lower plenum (length-to-diameter ratio of 2.8:1) and the thermal liner was installed in the lower plenum. The downcomer gap size was 0.5 inch. Two $100 \%$ break area nozzles were used in the cold leg of the blowdown loop.

(b) Test 1002. Test 1002 was conducted to establish the effects on the water remaining in the lower plenum following blowdown due to increased heat transfer from the lower plenum walls to the fluid. Therefore, the test was conducted without the thermal liner in the lower plenum. Except for the absence of the thermal liner the system configuration was identical to that of Test 1001 .

(c) Test 1003. Test 1003 was conducted to establish the effect on the water remaining in the lower plenum of altering the geometry of the lower plenum. For this test the length-to-diameter ratio of the lower plenum was $1.2: 1$ as compared to $2.8: 1$ for all utller tests. 
SUMMARY OF SEMISCALE ISOTHERMAL TESTS

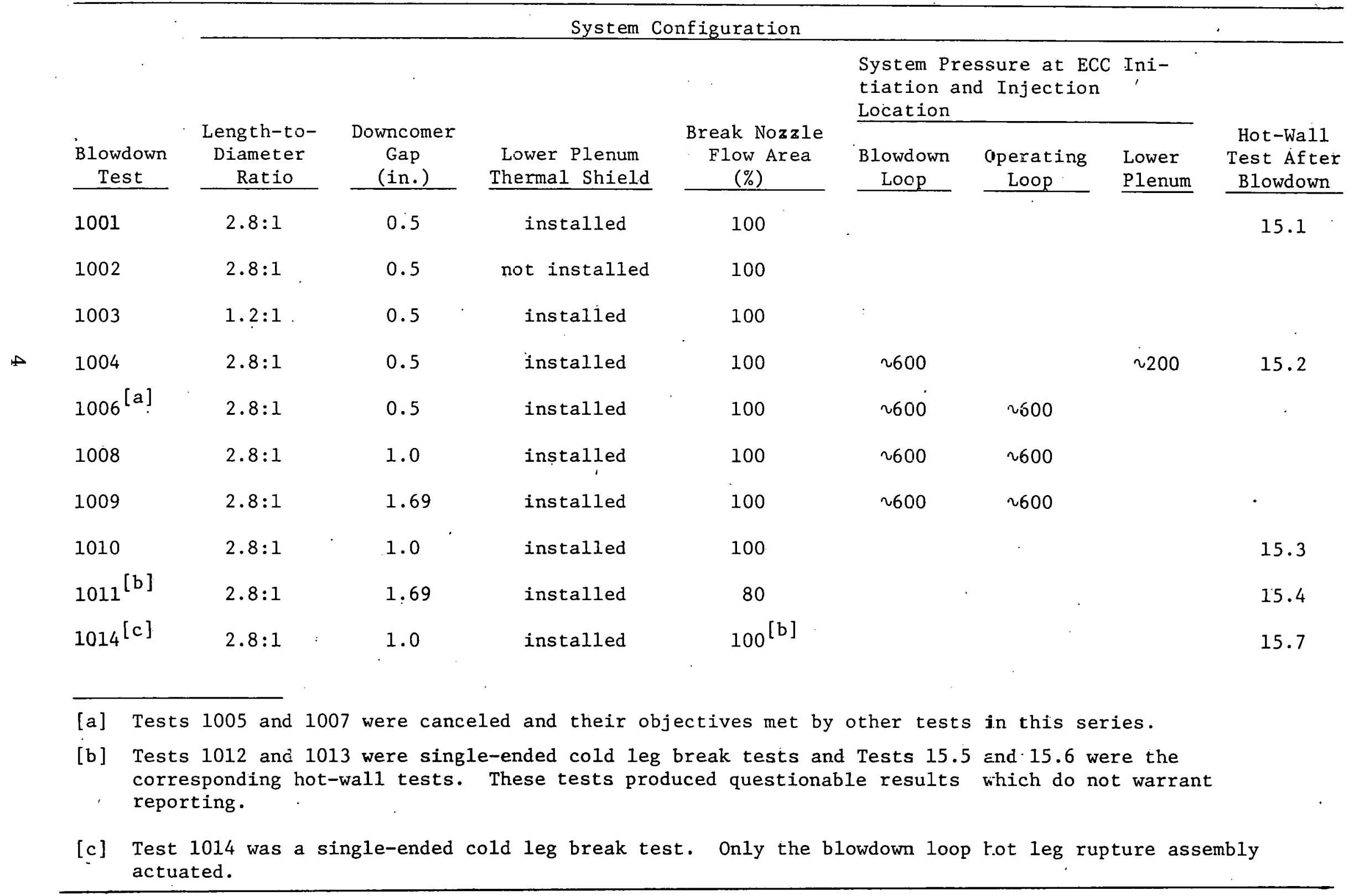


(d) Test 1004. Test 1004 was the first isothermal test conducted with ECC injection. For this test, ECC was injected into the lower plenum to determine effects on system flow and decompression of coolant mixing in the lower plenum. ECC was also injected upstream of the double-ended cold leg break on the simulated pump side of the break to determine the effect on break flow of coolant injection.

(e) Test 1006. Test 1006 was conducted to determine the capability of delivering coolant through the downcomer to the lower plenum. Coolant was injected into the cold leg of the operating loop and the cold leg of the blowdown loop (upstream of the cold leg break on the simulated pump discharge side).

(f) Test 1008. The purpose of Test 1008 was to investigate the effects of downcomer gap size on general hydraulic system behavior with the downcomer gap in the pressure vessel enlarged to 1.0 inch. ECC was injected into the cold legs of the operating and blowdown loops.

(g) Test 1009. Test 1009 investigated the effects of a large downcomer gap on downcomer flow and system general hydraulic behavior with the downcomer gap in the pressure vessel enlarged to $1.69 \mathrm{inch}$. ECC was injected into the cold legs of the operating and blowdown loops.

(h) Test 1010. Test 1010 was conducted with a 1.0-inch downcomer gap and no ECC injection to determine the effects of a 1.0-inch downcomer gap on system general hydraulic response.

(i) Test 1011. Test 1011 was conducted to provide data with which to assess analytical predictions against known system response to break size variation. The downcomer gap was 1.69 inches. The break flow area used in this test was $80 \%$ of that used in other isothermal tests. ECC was not injected.

(j) Test 1014. Test 1014 provided information on system hydraulic response to a single-ended cold leg break; system decompression occurred through the hot leg of the blowdown loop, the simulated steam generator, simulated pump, and a portion of the cold leg. This test was conducted with a 1.0-inch downcomer gap and without ECC injection.

\section{HOT-WALL TESTS}

To determine effects of stored wall heat on ECC delivery, the following hot-wall tests were conducted after completion of the blowdown tests.

(a) Test 15.1 was conducted following blowdown Test 1001

(b) Test 15.2 was conducted following blowdown Test 1004 
(c) Test 15.3 was conducted following blowdown Test 1010

(d) Test 15.4 was conducted following blowdown Test 1011

(e) Test 15.7 was conducted following blowdown Test 1014 .

These-tests were conducted with ECC injection continuing until the lower plenum was filled. 


\section{TEST APPARATUS}

The 1-1/2-loop isothermal semiscale system shown isometrically in Figure 1 and schematically in Figure 2 consists of a pressure vessel with simulated reactor internals (electric heaters); an operating loop with a steam generator, pump, and pressurizer; a blowdown loop with rupture assemblies, a simulated steam generator, and a simulated pump; a pressure suppression system with a suppression tank and header; and a simulated ECC system with accumulators and injection pumps. The exterior of the entire system and piping is thermally insulated.

The isothermal system is designed to operate at temperature and pressure of $577^{\circ} \mathrm{F}$ and 2250 psig. The operating loop simulates three operating loops of a commercial PWR, and the blowdown loop simulates a single operating loop of a PWR. When test conditions are established, the system is subjected to a simulated double-ended shear cold leg break.

System liquid volumes are recorded in Table II, and experimentally determined system pressure drops and calculated hydraulic resistances are given in Table III.

\section{PRESSURE VESSEL AND INTERNALS}

The pressure vessel, shown in Figure 3, is constructed of 10-inch Schedule 160 carbon steel pipe conforming to ASTM A 106, Grade B. It has a length of about 12 feet, an OD of 10.75 inches, and an ID of 8.5 inches. The top and bottom heads are 10 -inch Grayloc blind hubs, and the top head is fitted with a 4-inch Grayloc hub that supports an inner core barrel assembly. The vessel is designed for pressure and temperature of $2250 \mathrm{psig}$ and $650^{\circ} \mathrm{F}$. Six 3 -inch nozzle penetrations are provided in the vessel sides, two for inlet nozzles and four for outlet nozzles. Additional penetrations are provided in the vessel for installation of instrumentation.

The length and diameter of the vessel lower plenum are varied through use of two different bottom heads and a downcomer filler extension. The standard (long) lower plenum, with the downcomer filler extension installed, is 6.5 inches in diameter and 17.6 inches in depth. The other (short) lower plenum does not utilize the downcomer filler extension and is 8.5 inches in diameter and 10.3 inches in depth. The heat transfer characteristics of the lower plenum are varied by use of a thermal shield consisting of a thermal sleeve and a bottom thermal liner plate. The thermal sleeve is a 0.010 -inch-thick Type 304 stainless steel cylinder wrapped in 0.045-inch-thick Grafoil, a graphiteimpregnated insulation material. The bottom thermal liner plate is a flat sheet of 0.010-inch-thick Type 304 stainless steel with a 0.060-inch layer of Grafoil underneath.

The vessel internals (Figure 3) consist of a core barrel assembly and either of two instrumented downcomer filler pieces; one filler piece provides a downcomer gap (annulus) of 0.50 inch and the other provides a downcomer gap of 1.0 inch. A 1.69 -inch downcomer gap is obtained by omitting the filler pieces. The core barrel assembly has an outer core 


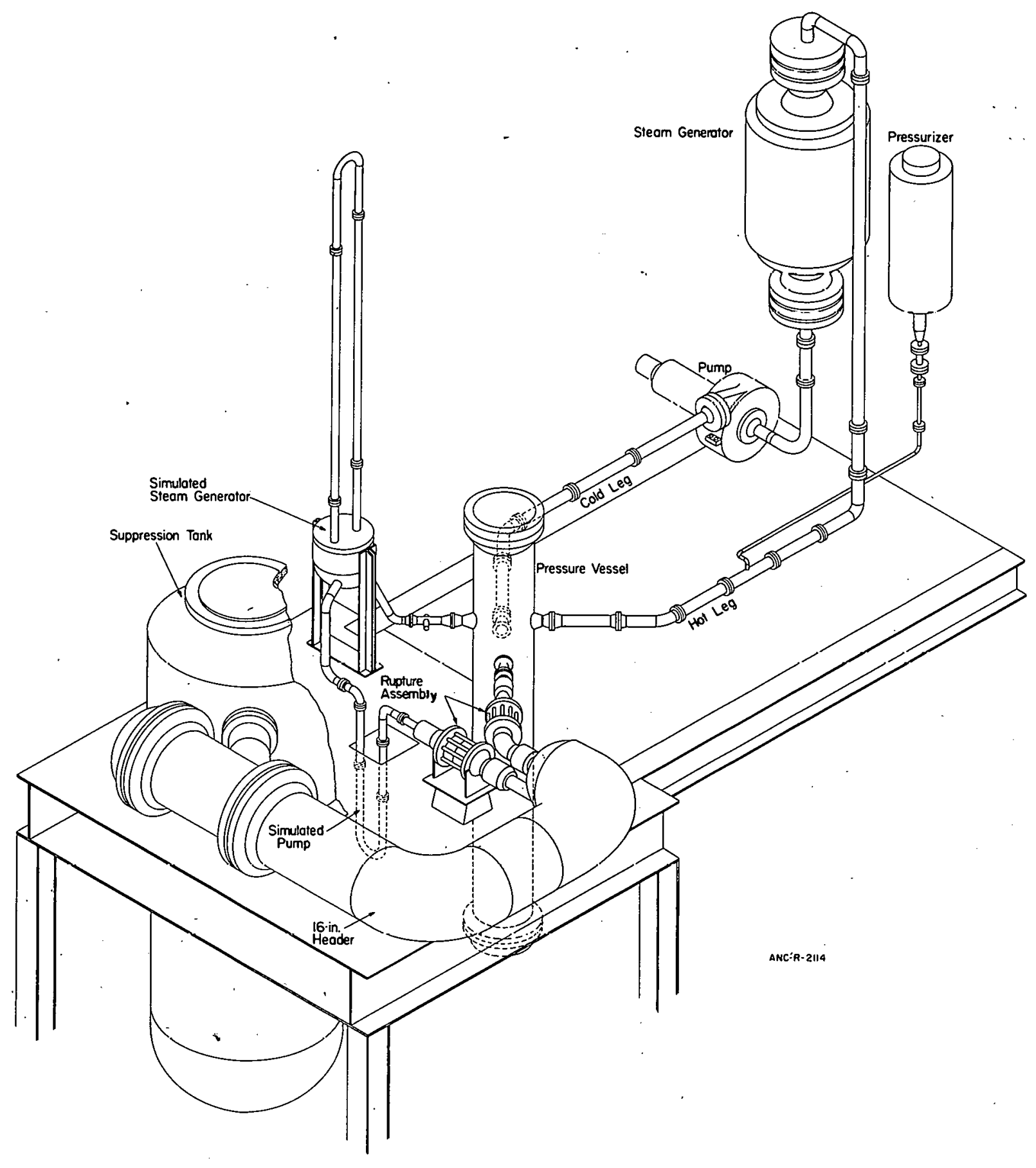

Fig. 1 1-1/2-loop semiscale system -- isometric. 


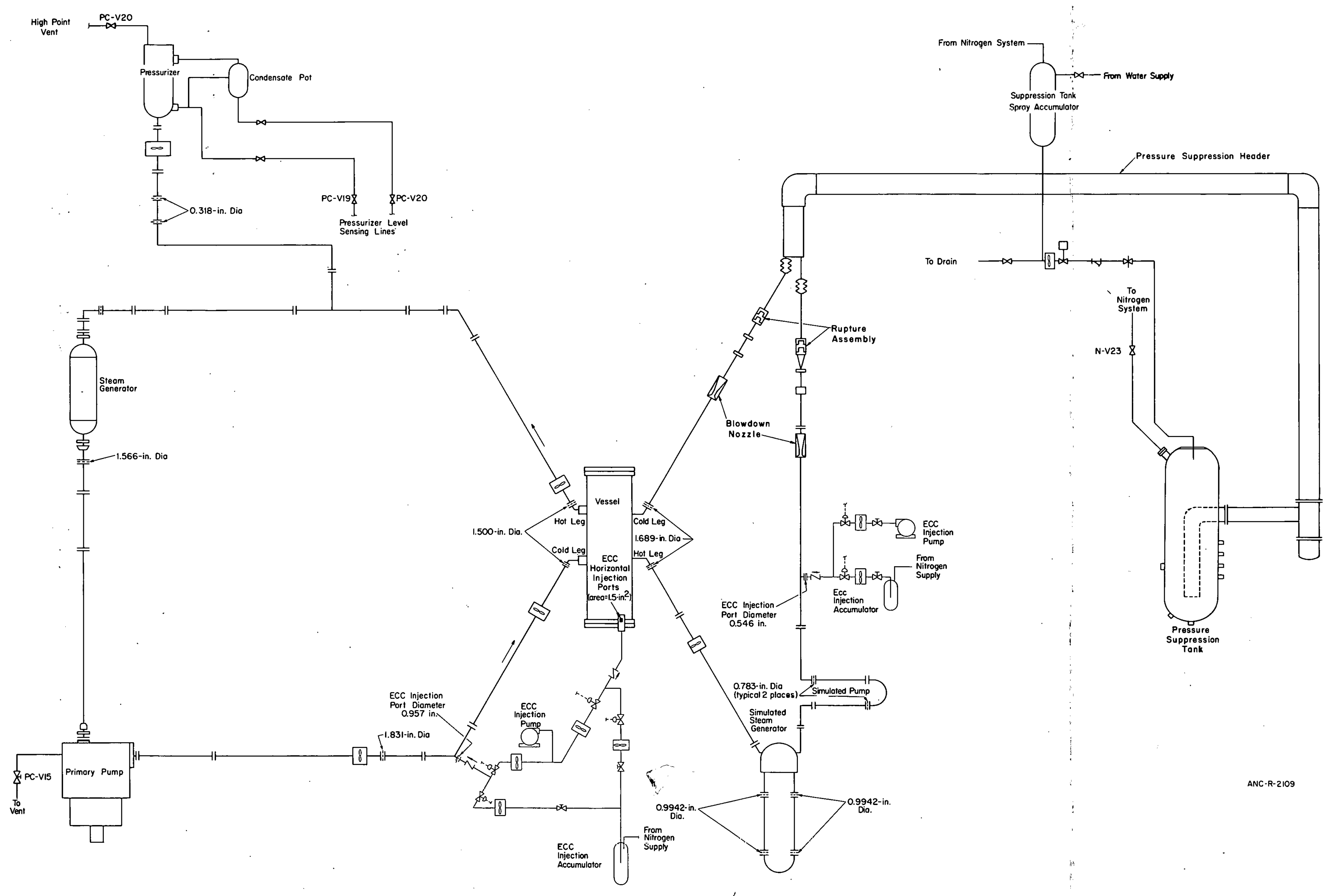

Fig. 2 1-1/2-loop semiscale system -- piping schematic. 
TABLE II

LIQUID VOLUME DISTRIBUTION FOR 1-1/2-LOOP ISOTHERMAL SYSTEM

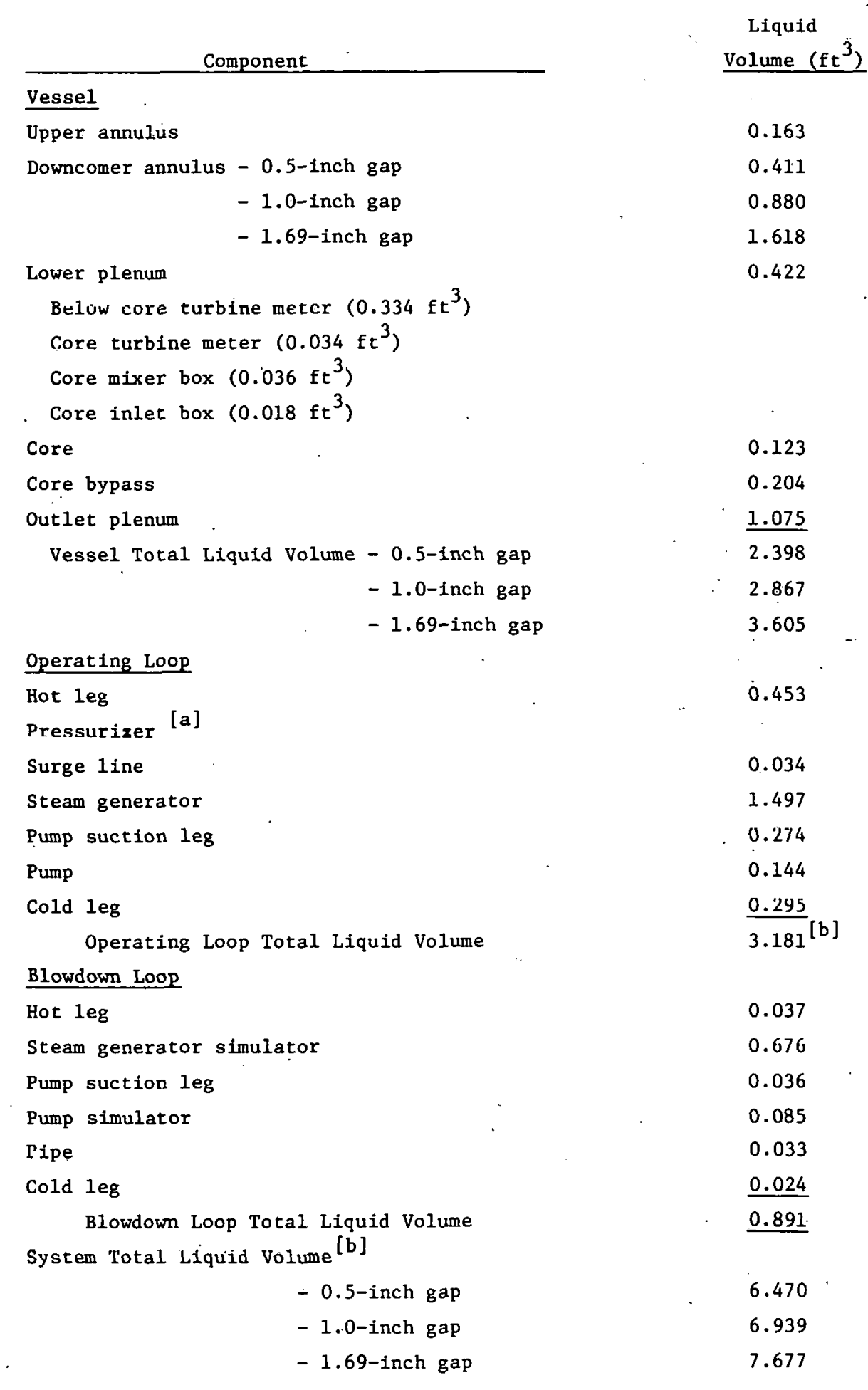

[a] Pressurizer liquid volume is a test variable. The total volume of

b] Excluding pressurizer 1iquid volume. 


\section{TABLE III}

MEASURED SYSTEM PRESSURE DROPS AND CALCULATED FLOW RESISTANCES

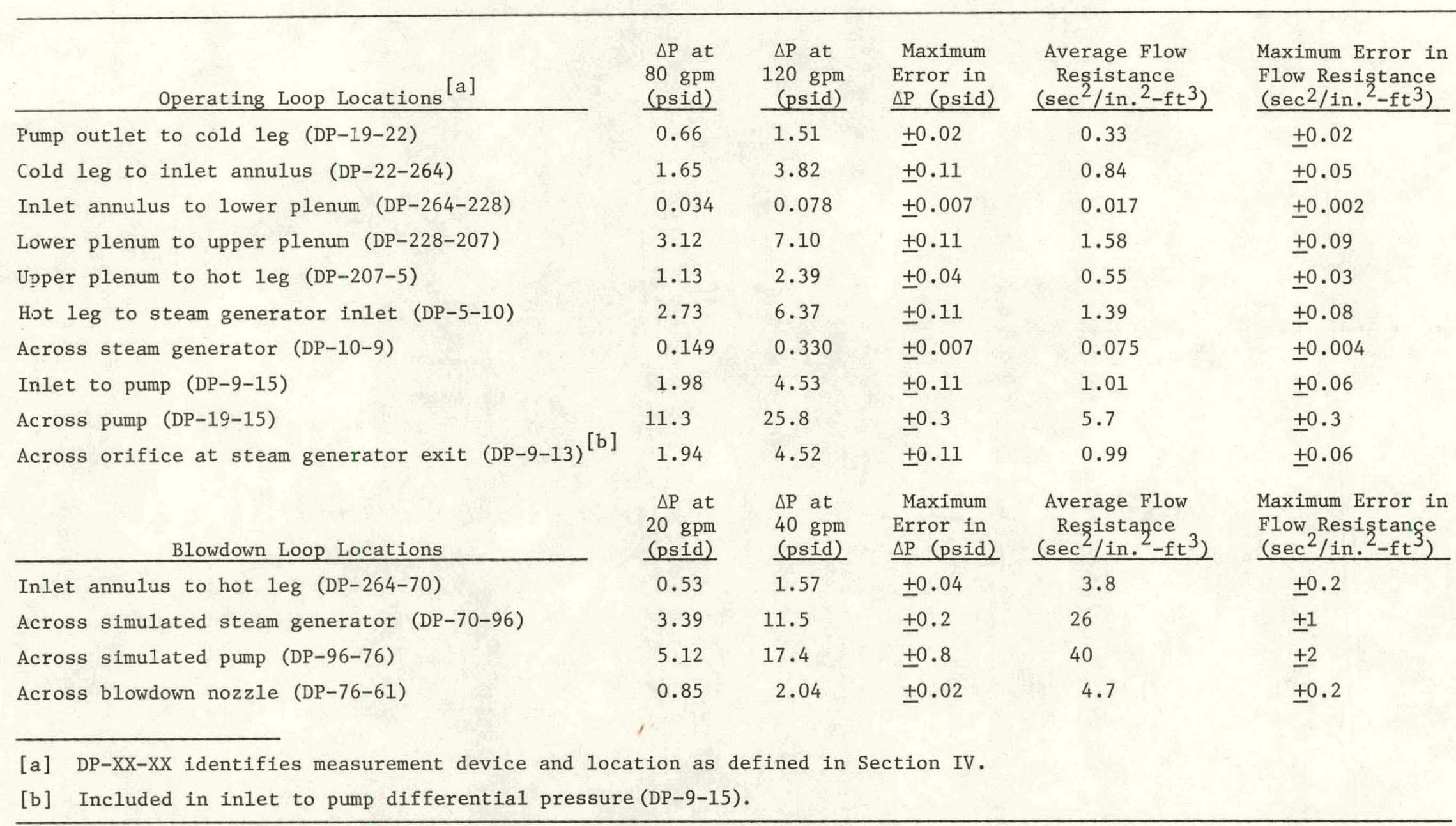




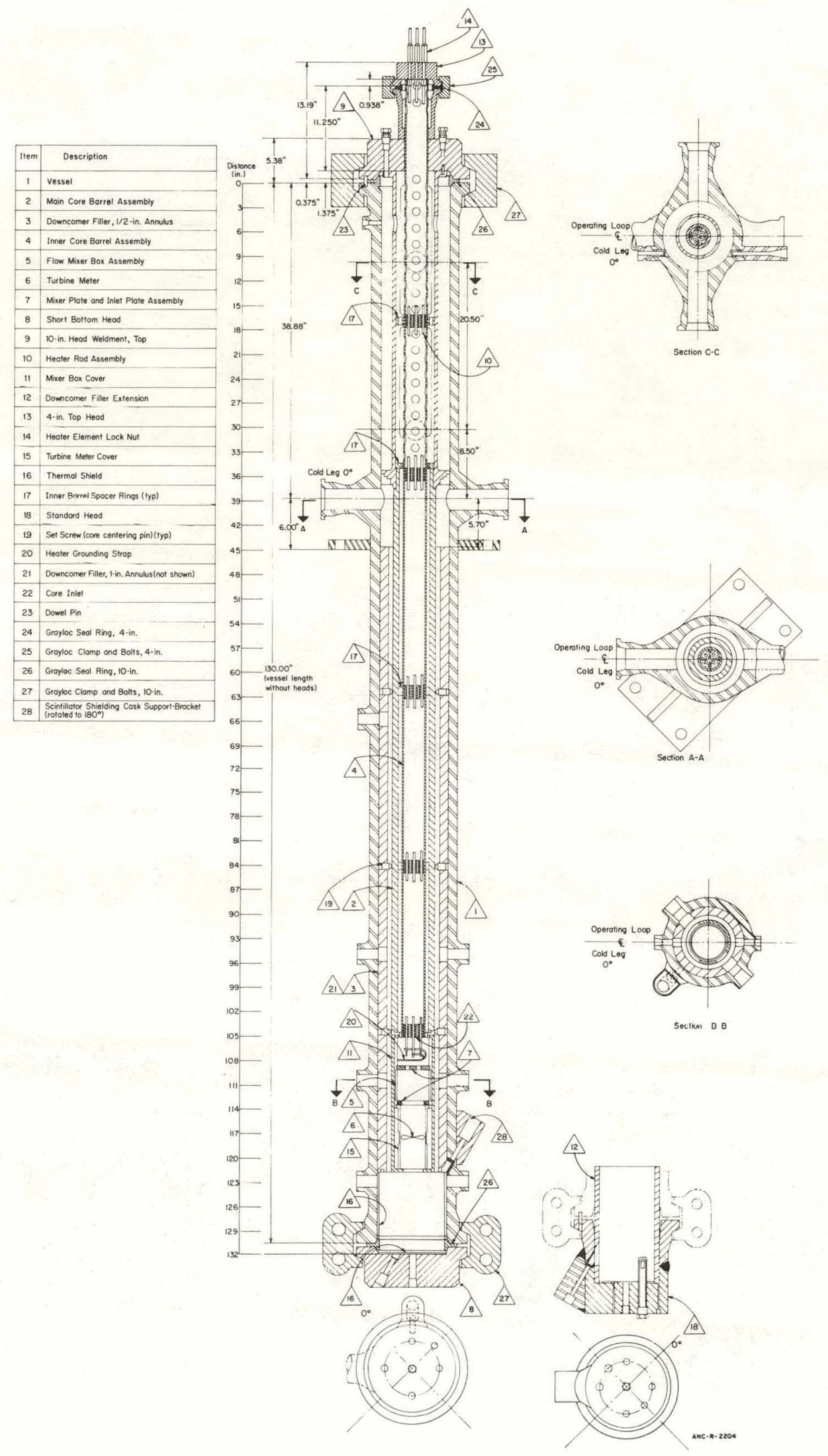

Fig. 3 Pressure vesse1, cross-sectional view. 
barrel (main core barrel assembly in Figure 3) suspended from the 10-inch top head weldment and an inner core barrel suspended from the 4-inch top head. Nine heater rods are suspended from the 4-inch top head and extend down through the inner core barrel. The inner core barrel is made from $2-3 / 4$-inch-OD by 0.188 -inch-thick stainless steel tubing. The outer core barrel is made from sections of 5-and 6-inch Schedule 80 Type carbon steel pipe conforming to ASTM A 106, Grade B (5-inch pipe in the downcomer annulus and 6-inch pipe in the upper annulus). The OD of the outer core barrel is about 5-1/4 inches.

The heater rods in the vessel heat the system water to isothermal conditions. The heaters are stainless steel-clad filament heaters about 10 feet long with a 66-inch heated section, and are arranged in a $3 \times 3$ array on approximately 0.56 -inch centers. Each heater rod has a diameter of approximately $0.42 \mathrm{inch}$, and each has a power capability of $30 \mathrm{~kW}$. The bottoms of the heater rods are electrically grounded to the outer core barrel. Six of the heater rods are connected to two dc sources; three rods are connected to a variable power source of $0-155 \mathrm{Vdc}$, and three rods are connected to a constant (155 Vdc) power source. The three remaining rods are not powered. For the isothermal tests, power to all heater rods is turned off before blowdown is initiated.

The coolant, chemically treated demineralized water, enters the vessel inlet annulus through the cold leg inlet nozzle and flows down to the lower plenum through the downcomer annulus formed by the inside of the downcomer filler piece and the outside of the outer core barrel. The coolant then flows up through a turbine flowmeter and then through the nine-rod heater bundle. A portion of the coolant bypasses the heater bundle by flowing between the inside of the outer core barrel and the outside of the inner core barrel. The amount of bypass flow is controlled by spacer rings which restrict the flow passage. The coolant then flows out the openings in the inner barrel and slots in the outer barrel to the vessel outlet plenum and vessel outlet nozzles. An 0-ring seal is used to separate the outlet plenum from the inlet annulus.

Nozzle liners are used to reduce the 2.689-inch-ID vessel nozzles to 1.5 -inch ID for the operating loop and to 1.689-inch ID for the blowdown loop. The vessel is designed for a pressure drop (nozzle-to-nozzle) of $52 \mathrm{psig}$ at a vessel flow rate of $30 \mathrm{lb} / \mathrm{sec}$.

\section{OPERATING LOOP}

The operating loop consists of the primary coolant piping, steam generator, pressurizer, and circulating pump. The operating loop is shown in the system schematic of Figure 2.

\subsection{Operating Loop Piping}

The primary coolant piping is primarily 3-inch Schedule 160, carbon steel pipe conforming to ASTM A 106, Grade B. The piping consists of replaceable spool piece 
sections which are connected by 3-inch Grayloc fittings. Carbon steel is used for the Grayloc fittings and most of the piping, but Type 316 stainless steel is used for spool pieces containing turbine flowmeters. Pipe spools for instrumentation are 17-1/4 inches long and provide the capability for changing measurement locations. Pipe section lengths of the primary coolant piping in the operating loop are as follows:

Hot leg (vessel to steam generator)

Pump suction (steam generator to pump)

Cold leg (pump to vessel)

Total operating loop piping
167.22 in.

87.81 in.

$98.66 \mathrm{in.}$

353.69 in.

\subsection{Steam Generator}

The steam generator is a tube-in-shell heat exchanger, as illustrated in Figure 4. The primary coolant flows into the inlet plenum, downward through 43 coolant tubes, into the outlet plenum, and out the exit nozzle. The tests of the isothermal series were conducted with the temperature drop around the primary loop kept to a minimum; no secondary cooling was used.

The steam generator is fabricated from carbon steel in accordance with the requirements of Section VIII of the ASME Boiler and Pressure Vessel Code; the primary coolant side has a design pressure and temperature of 2500 psig and $650^{\circ} \mathrm{F}$, respectively. Distribution of volume within the steam generator is as follows:

$\begin{array}{lc}\text { Inlet nozzle and upper plenum } & 0.47 \mathrm{ft}^{3} \\ \text { Tube volume } & 0.20 \mathrm{ft}^{3} \\ \text { Lower plenum and outlet nozzle } & \frac{0.47 \mathrm{ft}^{3}}{1.14 \mathrm{ft}^{3}} \\ \text { Total } & \end{array}$

\subsection{Pressurizer}

The pressurizer is an electrically heated vessel connected to the primary piping between the pressure vessel and the steam generator inlet. Pressurizer operation is similar to that of its counterpart in a PWR in that the water in the partially filled pressurizer is maintained at the saturation temperature corresponding to the desired system pressure.

The pressurizer is designed for 2500 psig and $650^{\circ} \mathrm{F}$ and was hydro-tested to 4725 psig. It is made of 10 -inch double extra strong Type 304 stainless steel pipe 45 inches long. Heâe is supplied by thirty-two $0.25-\mathrm{kW}$ heaters which are inserted down through the top of 


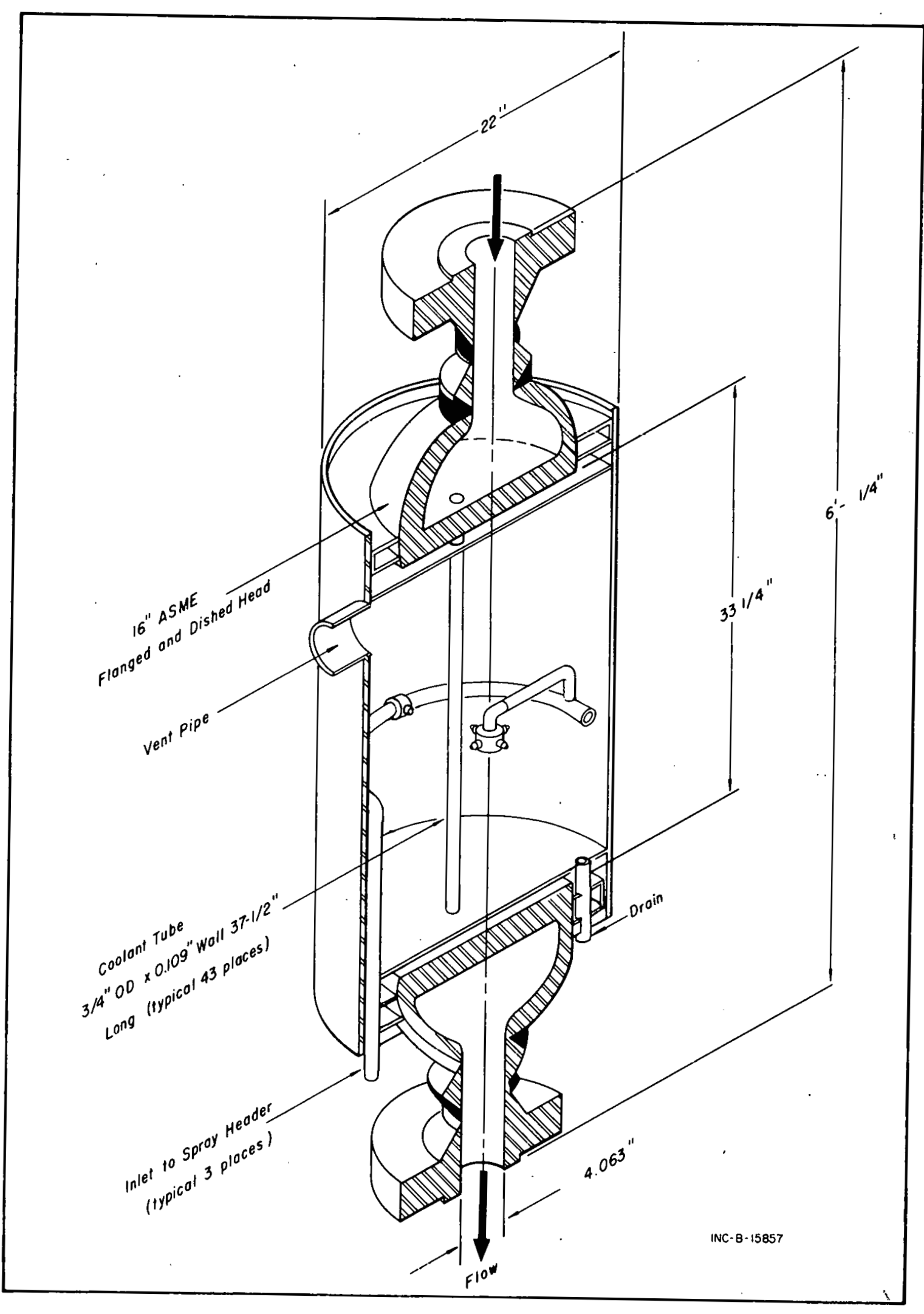

Fig. I Steam generator, cross-sectional view. 
the pressurizer into dry wells. The wells are vertically mounted 0.75 -inch-OD stainless steel tubes with closed bottom ends. The wells are integral with the pressurizer top and extend downward almost to the bottom of the pressurizer. The hot leg of the primary piping is connected to the pressurizer by $3 / 4$-inch Schedule 80 pipe. A restriction for flow resistance is used during the decompression phase of testing. The total volume of the pressurizer and surge line piping is $1.002 \mathrm{ft}^{3}$.

\subsection{Circulating Pump}

The circulating pump is a volute-type, heavy-duty, horizontal centrifugal pump rated for a nominal flow of $182 \mathrm{gpm}$ at a total head of $192 \mathrm{ft}$ of water at $3560 \mathrm{rpm}$. The material of construction for the wetted parts (casing, impeller, shaft, ...) is Type 316 stainless steel. The remainder of the pump is of cast iron and carbon steel. The pump is designed for 2500 psig and $650^{\circ} \mathrm{F}$. The specific speed of the pump is $930 \mathrm{rpm}$, the impeller diameter is $7-3 / 4$ inches, and the total pump volume is $0.144 \mathrm{ft}^{3}$. The pump is belt-driven through an integral torque motor by a $15 \mathrm{hp}$, variable speed, dc electric motor. Through use of the dc motor and speed controller, the pump can be set to operate at any speed between 250 and 3500 $\mathrm{rpm}$. The operating conditions for the isothermal tests were attained by a pump speed of about $3000 \mathrm{rpm}$.

\section{BLOWDOWN LOOP}

The blowdown loop consists of a simulated pump, a simulated steam generator, two discharge nozzles, two rupture assemblies, and associated piping as illustrated in Figures 1 and 2 .

\subsection{Piping}

The piping in the blowdown loop is 2 -inch Schedule 160 carbon steel. The inside diameter of the 3-inch Schedule 160 vessel inlet and outlet nozzles is reduced from 2.626 inches to 1.689 inches by installation of a sleeve in each nozzle. With the exception of the flanges holding the rupture assemblies, all pipe flanges are 2-inch Grayloc fittings. Those holding the rupture assemblies are 2-1/2-inch 1500-lb flanges. Pipe section length in the blowdown loop are as follows:

\section{Cold Leg}

Simulated pump outlet to rupture

disc assembly

20.15 in.

Rupture disc assembly to vessel

22.37 in.

Simulated Steam Generator

$23.69 \mathrm{in}$.

Pump Suction (simulated steam generator to simulated pump)

27.96 in. 
Hot Leg (vessel to simulated steam generator)

28.74 in.

Total Blowdown Loop Piping

188.33 in

In order to establish isothermal conditions throughout the system, circulation of the fluid in the blowdown piping is maintained prior to blowdown by flowing a small amount of fluid through a $1 / 2$-inch line from the cold leg to the hot leg. The flow rate is controlled by an air-operated modulating valve in the $1 / 2$-inch line connecting the two legs. The $1 / 2$-inch connecting line is closed off just prior to blowdown.

\subsection{Simulated Steam Generator and Simulated Pump}

The steam generator is simulated with an inlet-outlet plenum chamber of 536-in. ${ }^{3}$ volume, a 2 -inch Schedule $160 \mathrm{U}$-shaped pipe of $572-\mathrm{in.}^{3}$ volume connecting the two plenums, and a restricting orifice. The maximum height of the centerline of the U-shaped pipe line is 133 inches above the centerline of the hot leg. Four orifices (0.9942-in. diameter) are installed in the steam generator simulator to produce the desired hydraulic resistance.

The blowdown coolant pump resistance is simulated with two orifices (0.783-in. diameter). The pump suction piping is simulated with a U-trap of 2-inch Schedule 160 pipe 49.5 inches deep. It is connected to the system with Grayloc fittings.

\subsection{Rupture Assemblies}

Each rupture assembly consists of the blowdown nozzle, two 1450-psi banana-peel-type rupture discs, and an instrument washer bolted between two 2-1/2-inch 1500-pound slip-on flanges. Figure 5 shows the rupture assembly (without the blowdown nozzle) and Figures 6 and 7 show the different nozzle configurations used. The chamber between the rupture discs is filled with helium to about one-half the primary system pressure. When the operating pressure is reached within the primary system, the discs are ruptured by the helium being vented from the chamber to increase the differential pressure between the cavity and the primary system, causing the primary system pressure to rupture the inner (blowdown loop side) disc first and then the outer (suppression system side) disc. Also included as part of each rupture assembly is a convergent-divergent nozzle (Figures 6 and 7).

Each of the rupture nozzles is designed to simulate one-half of a double-ended shear break in a PWR primary system cold leg. The nozzles used for the $100 \%$ break area tests are sized to produce a system volume to break area ratio representative of a complete break and offset of a reactor main coolant pipe. The two $100 \%$ break area nozzles provide a system volume to total break area ratio of 1481 feet which is representative of a PWR break. The

area of each of the two $80 \%$ break area nozzles is $80 \%$ of the area of the $100 \%$ nozzle. The 

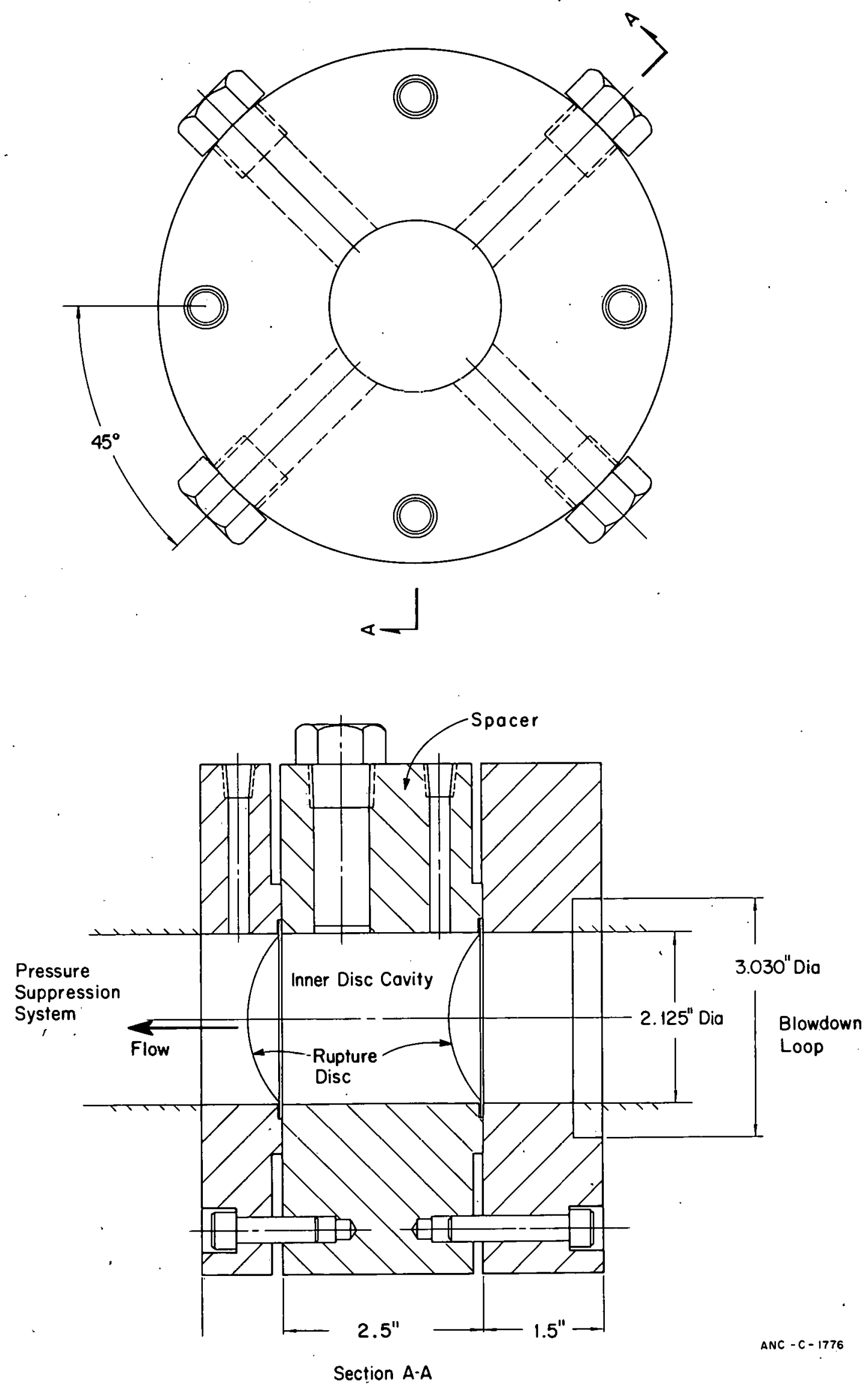

Fig. 5 Rupture assembly. 
(1) (2), (3) and (4) Indicate Pressure

Tap HN1, HN2, HN3, and HN4, Respectively

Detoil A $\quad 0.339^{\prime \prime} \mathrm{Dio}$
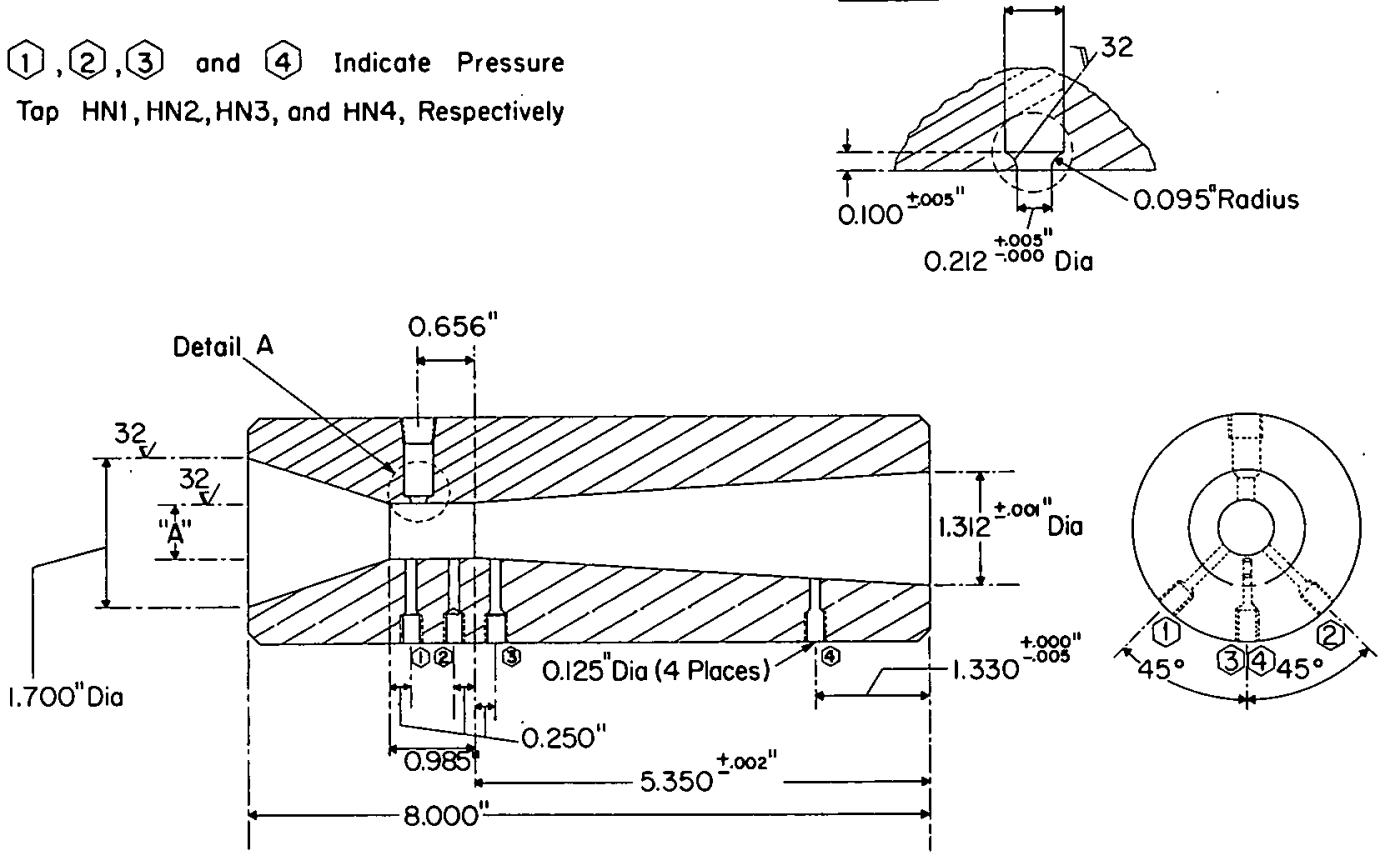

(1) and (3) Rotated $45^{\circ}$ for Clarity

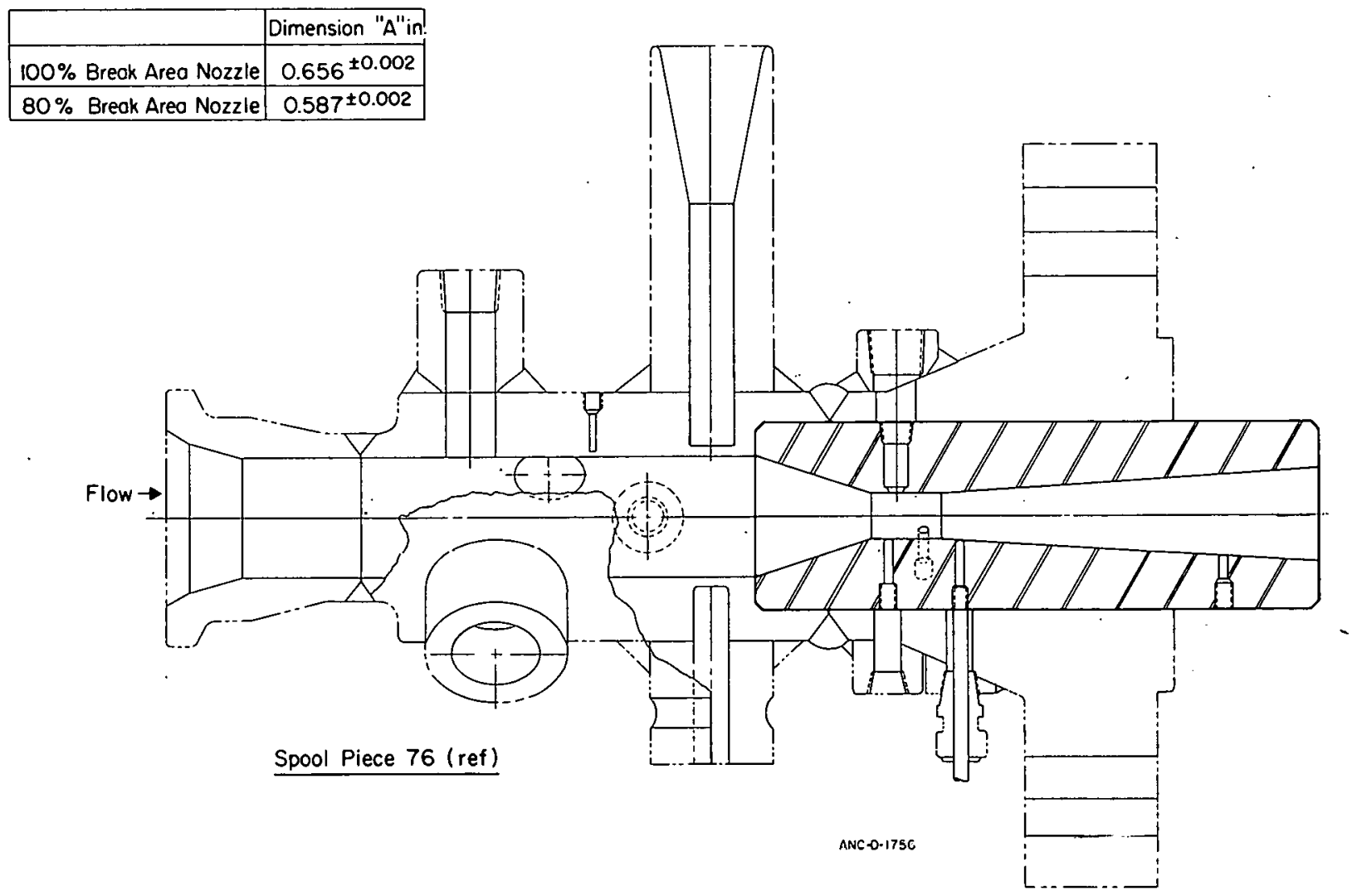

Fig. 6 Hot leg break nozzle assemhly. 


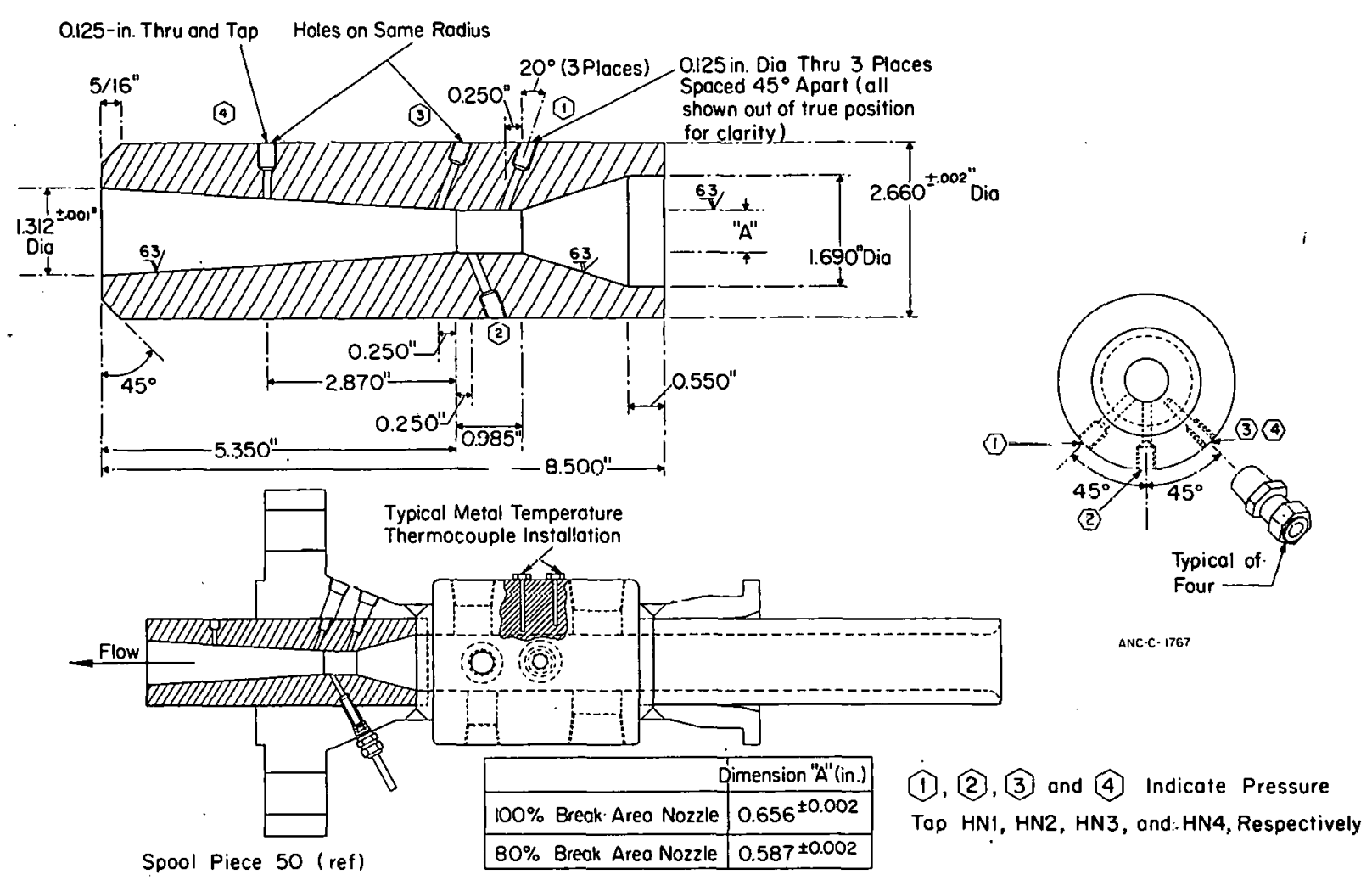

Fig. 7 Cold leg break nozzle assembly.

term cold leg nozzle refers to the nozzle on the pressure vessel side of the break, and the term hot leg nozzle refers to the nozzle on the simulated pump side of the break.

\section{PRESSURE SUPPRESSION SYSTEM}

The 1-1/2-loop pressure suppression system consists mainly of a pressure vessel with a downcomer and blowdown header as shown in Figure 1. Its function is to simulate the secondary containment vessel of a PWR. Blowdown effluent is discharged from the blowdown loop into a 16-inch header that simulates, in general, the drywell in a PWR pressure suppression system. The effluent flows from the header into the vessel water pool through an 8-inch downcomer. The pressure suppression vessel is oriented vertically to achieve the desired distance from the downcomer to the water surface and to the bottom of the vessel. The pressure suppression system accepts $100 \%$ of the blowdown water in the 1-1/2-loop primary system, the initial suppression vessel water, and the injected ECC water. 


\subsection{Pressure Suppression Tank}

The total volume of the pressure suppression tank is $91.7 \mathrm{ft}^{3}$. The tank is sized such that when it is $50 \%$ full of water, the downcomer pipe extends 2.5 feet below the water surface. Fill and drain connections are provided at the bottom of the tank and a gas pressurization nozzle is located near the top. A flanged connection is provided for the downcomer pipe. A 3-inch Schedule 40 flanged nozzle (with blind flange installed) is located in the top of the tank to provide access for spray equipment used. in some isothermal tests for pressure control. Heaters are provided to maintain the desired water temperature prior to blowdown.

The downcomer pipe is 8-inch Schedule 40 carbon steel and extends downward to 3.0 feet from the bottom of the tank. Either two 1-1/2-inch vacuum breaker valves or three 1-1/2-inch check valves are provided to prevent suction of water up the downcomer after completion of the blowdown.

\subsection{Pressure Suppression Header}

The header is made of 16-inch Schedule 40 carbon steel pipe and has a length-to-diameter of $8.4: 1$. No water traps exist in the header, and the downcomer pipe connection is on the bottom of the header.

\section{ECC INJECTION SYSTEM}

The ECC injection system consists of two accumulator subsystems and two pump subsystems. The system can supply simulated emergency core coolant to the pressure vessel lower plenum or to the operating loop and the blowdown loop as shown in Figure 2. The ECC injection system was designed to provide simulated core cooling to the operating loop and to the blowdown loop in identical ratios of ECC flow to loop volume; that is, the operating loop ECC system (scaled to represent three injection systems of a typical PWR) provides about three times the flow of the blowdown loop ECC system (simulates the injection system of the broken loop of a typical PWR).

\section{$5.1 \quad$ Accumulators}

Two accumulators, which are connected to a pressure source of gaseous nitrogen, supply initial water flows to the operating loop or lower plenum and blowdown loop. The accumulator which supplies the operating loop or lower plenum has a volume of $7.7 \mathrm{ft}^{3}$, and the accumulator which supplies the blowdown loop has a volume of $2.15 \mathrm{ft}^{3}$.

\subsection{Pumps}

Two positive displacement gear-type pumps independently supplement the expended accumulator flow. These puinips pruvide the capability of low pressure flows which can be varied from test to test. 


\subsection{Isolation Valves}

Six high-temperature, high-pressure, pneumatically operated and electrically controlled valves isolate the ECC injection system from the primary system. Valve operation is controlled by automatic timing devices or by remote manual control at the operations console.

\subsection{Check Valves}

Check valves were installed as close as practical to the primary system to minimize effects of an additional volume of fluid in the primary system. 


\section{INSTRUMENTATION}

The instrumentation system, shown schematically in Figure 8, provides the means for measuring test variables, recording the resultant data on magnetic tape, and producing the data in printed form.

Two hundred and twenty signal conditioning and recording channels are available of which 169 channels provide magnetic tape analog data. Digital data may be obtained from all 220 channels for warmup and backup use. The analog data are provided as X-Y plots with time referenced to test initiation as the absicissa. Time recording is provided by a timing subsystem, and time is recorded on the first channel of each magnetic tape transport.

\section{INSTRUMENT SYSTEM CONFIGURATION}

Measurement of test variables is accomplished by detectors located in the isothermal semiscale system. Detectors are provided for measuring fluid mass and volumetric flow rate, density, pressure, differential pressure, fluid and material temperatures, material strain, liquid level, and pump power, speed, and torque. The nomenclature used to designate specific detectors consists of (a) alphabetic symbols identifying the type of measurement (or detector type) or the location of the measurement relative to a component of the semiscale system, or both, and (b) arabic numeral suffixes to the alphabetic symbols identifying the pipe section (spool) or vessel port (station). Examples of detector designations are:

P-1 Indicates a pressure measurement in Pipe Section 1 (the hot leg of the operating loop).

DP-1-5 Indicates a differential pressure measurement between Pipe Sections 1 and 5.

FD-1 Indicates a measurement of fluid momentum flux with a drag disc in Pipe Section 1 .

Table IV defines the alphabetical nomenclature, and Figures 9 through 12 identify measurement stations and all instrumentation used in the isothermal blowdown tests. Figure 13 shows a typical installation for the detectors in an instrumented spool piece. Instrumented spool pieces (Spools 1, 19, 22, 41, and 70) are constructed of Type 304 stainless steel. Table $\mathrm{V}$.defines in greater detail the location of each measurement used in the isothermal test series. Table VI indicates the manufacturer of the detector, identifies the type of measurement device, indicates the range and response of the detector, and specifies the maximum error introduced by the measurement system. 


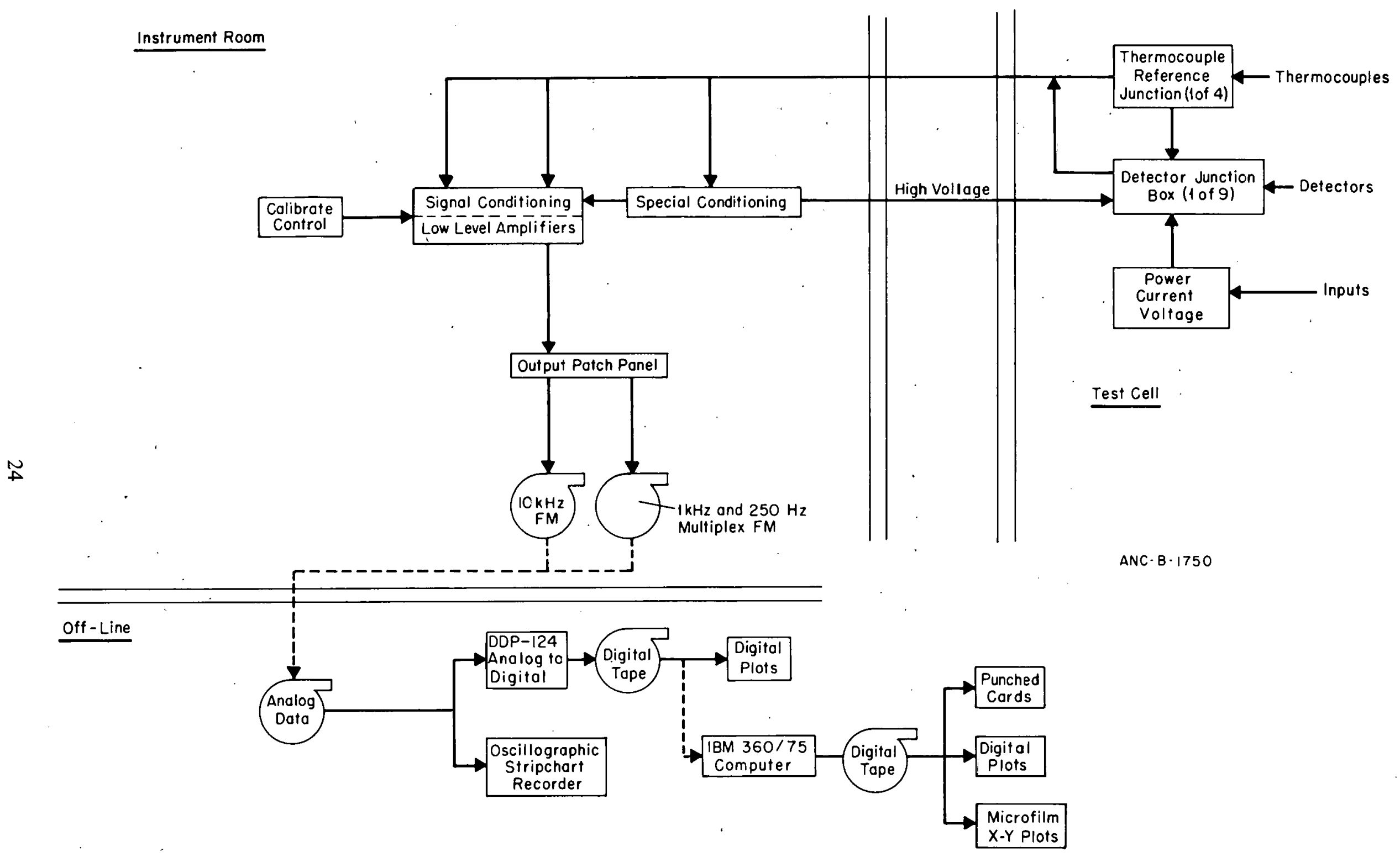

Fig. 8 Instrumentation system schematic. 
TABLE IV

DETECTOR DESIGNATIONS

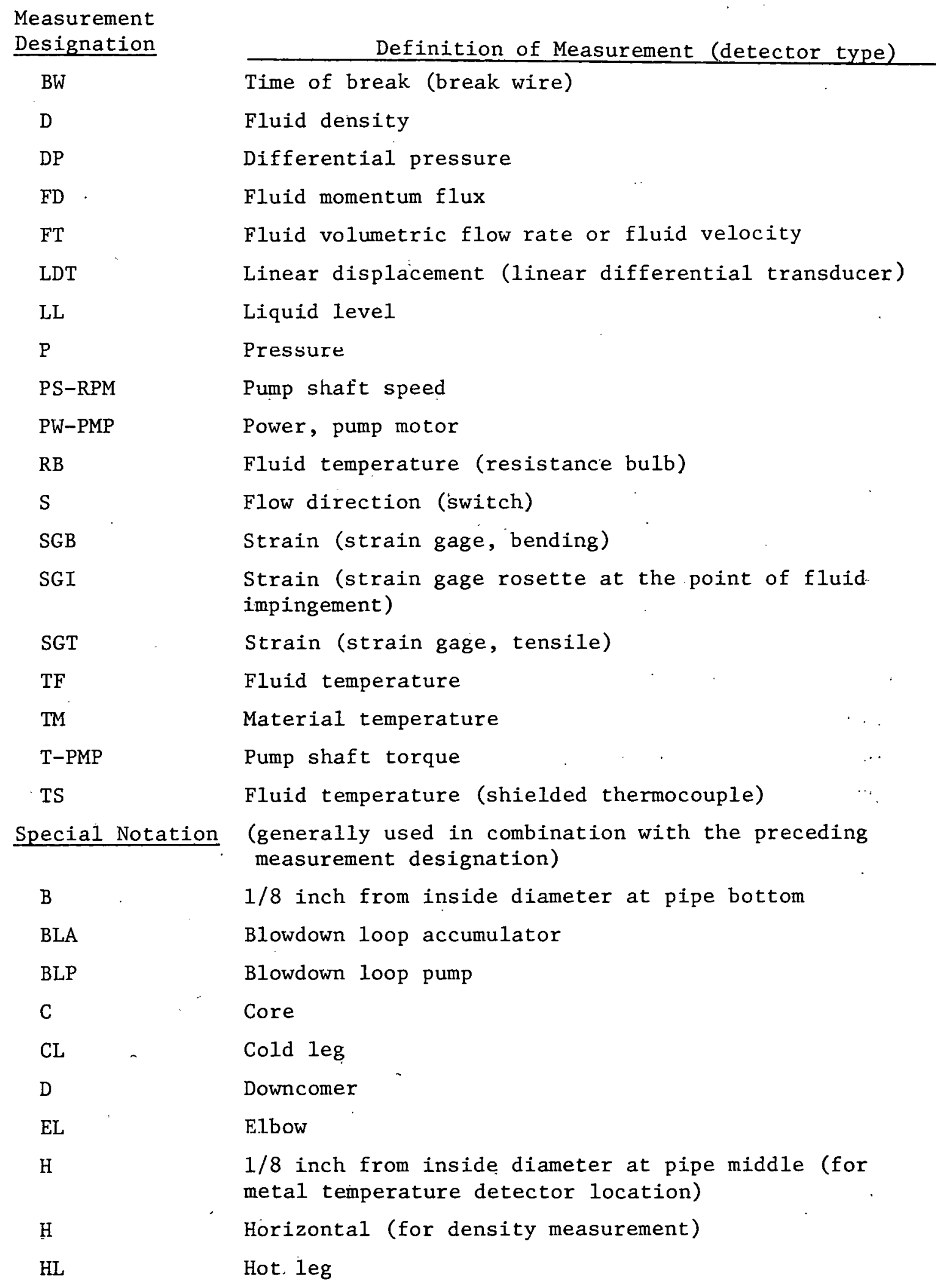


TABLE IV (Contd.)

DETECTOR DESIGNATIONS

\begin{tabular}{|c|c|}
\hline $\begin{array}{l}\text { Measurement } \\
\text { Designation }\end{array}$ & Definition of Measurement (detector type) \\
\hline \multicolumn{2}{|c|}{ Special Notation (Contd.) } \\
\hline HN & $\begin{array}{l}\text { Rupture nozzle (HN followed by a numeral indicates } \\
\text { nozzle instrument port) }\end{array}$ \\
\hline I & $1 / 8$ inch from inside diameter at pipe top \\
\hline IDL & Inside diameter, lower \\
\hline IDU & Inside diameter, upper \\
\hline $\mathrm{L}$ & Low range \\
\hline LFF & LOFT free field \\
\hline LFTA & LOFT analog \\
\hline LFTD & LOFT digital \\
\hline LH & Lower plenum head \\
\hline LOFT & Loss of fluid test \\
\hline LP & Lower plenum \\
\hline LPA & Lower plenum accumulator \\
\hline $\mathrm{M}$ & $1 / 4$ inch from inside diameter at pipe top \\
\hline OL & Operating loop \\
\hline OLA & Operating loop accumulator \\
\hline OLP & Operating loop pump \\
\hline PSH & Pressure suppression header \\
\hline PSS & Pressure suppression system \\
\hline PSV & Pressure suppression vessel \\
\hline $\mathrm{S}$ & Surface \\
\hline $\mathrm{V}$ & Vessel (with TM) or vertical (with D) \\
\hline VOD & Vessel outside diameter \\
\hline
\end{tabular}




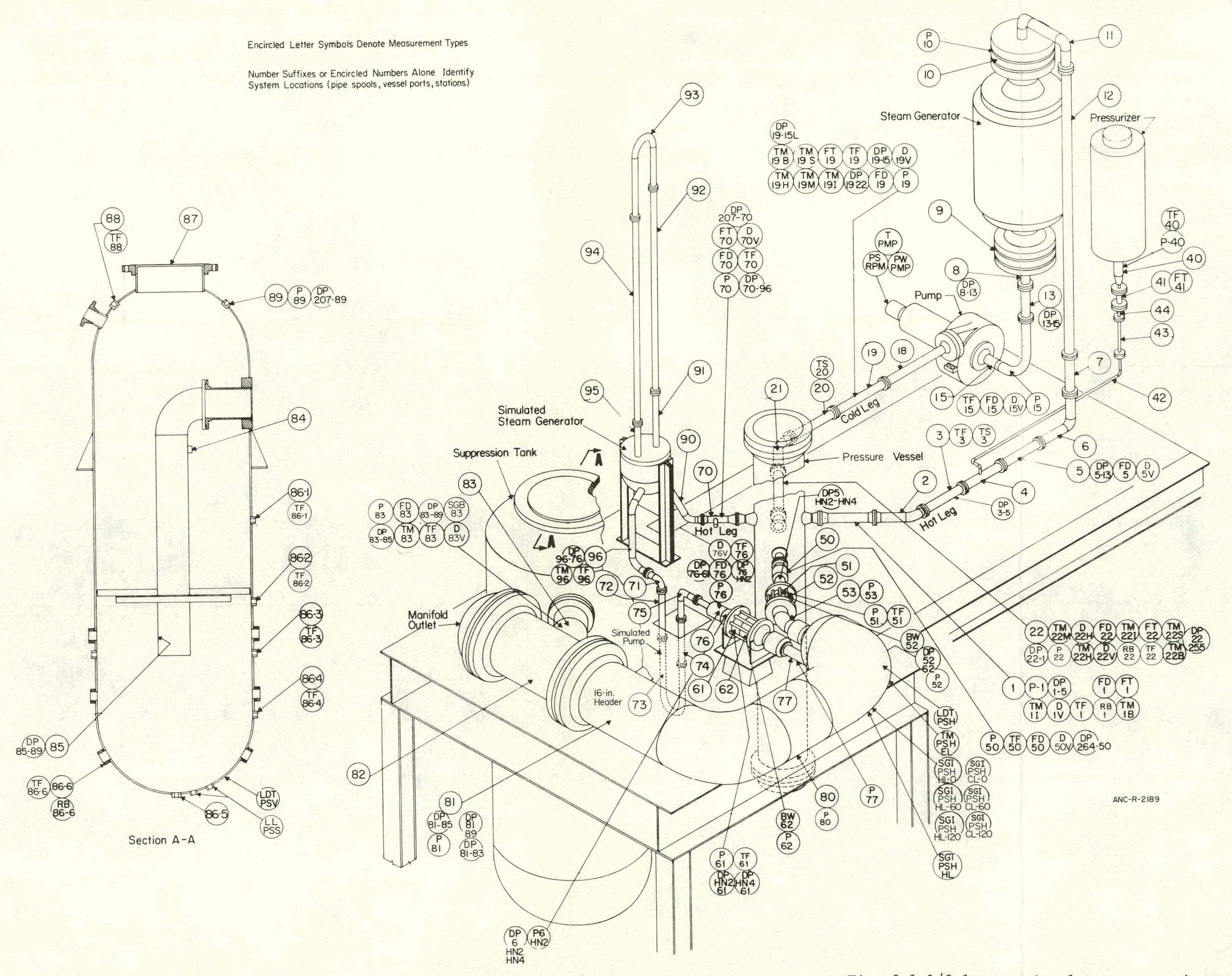

Fig. 9 1-1/2-1oop semiscale system -- instrumentation isometric. 


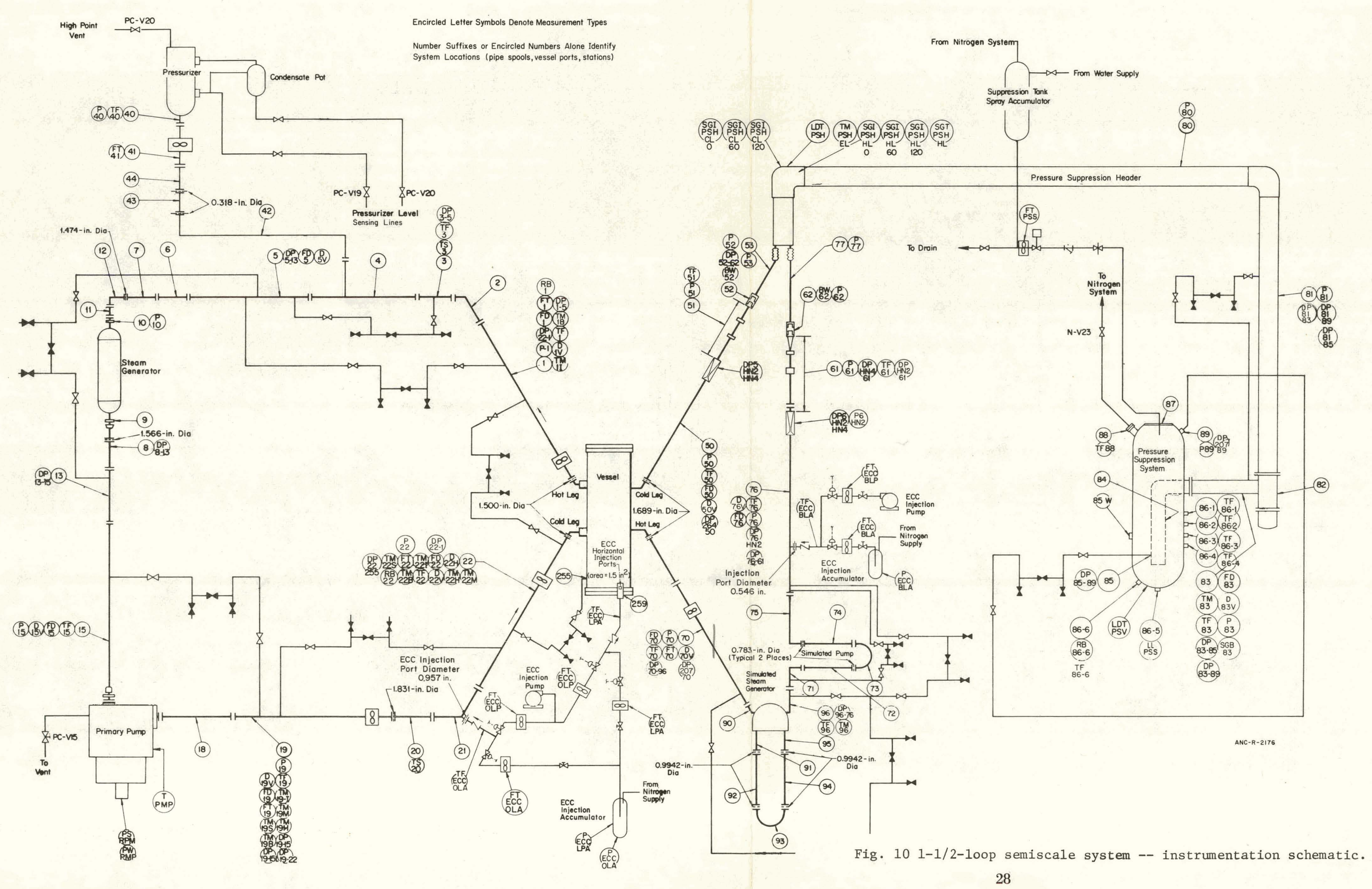




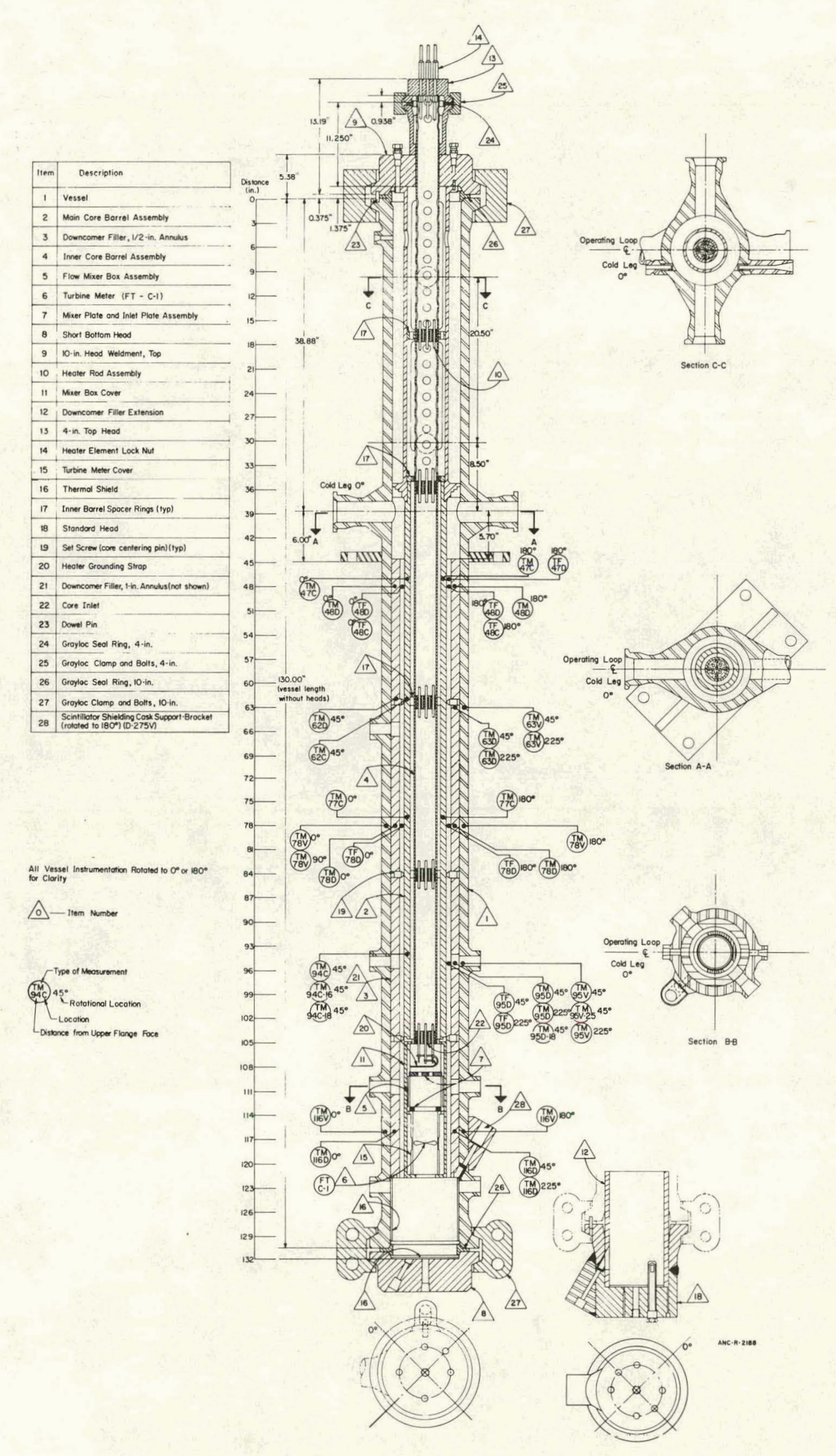

Fig. 11 Pressure vessel with instrumentation, cross-sectional view. 

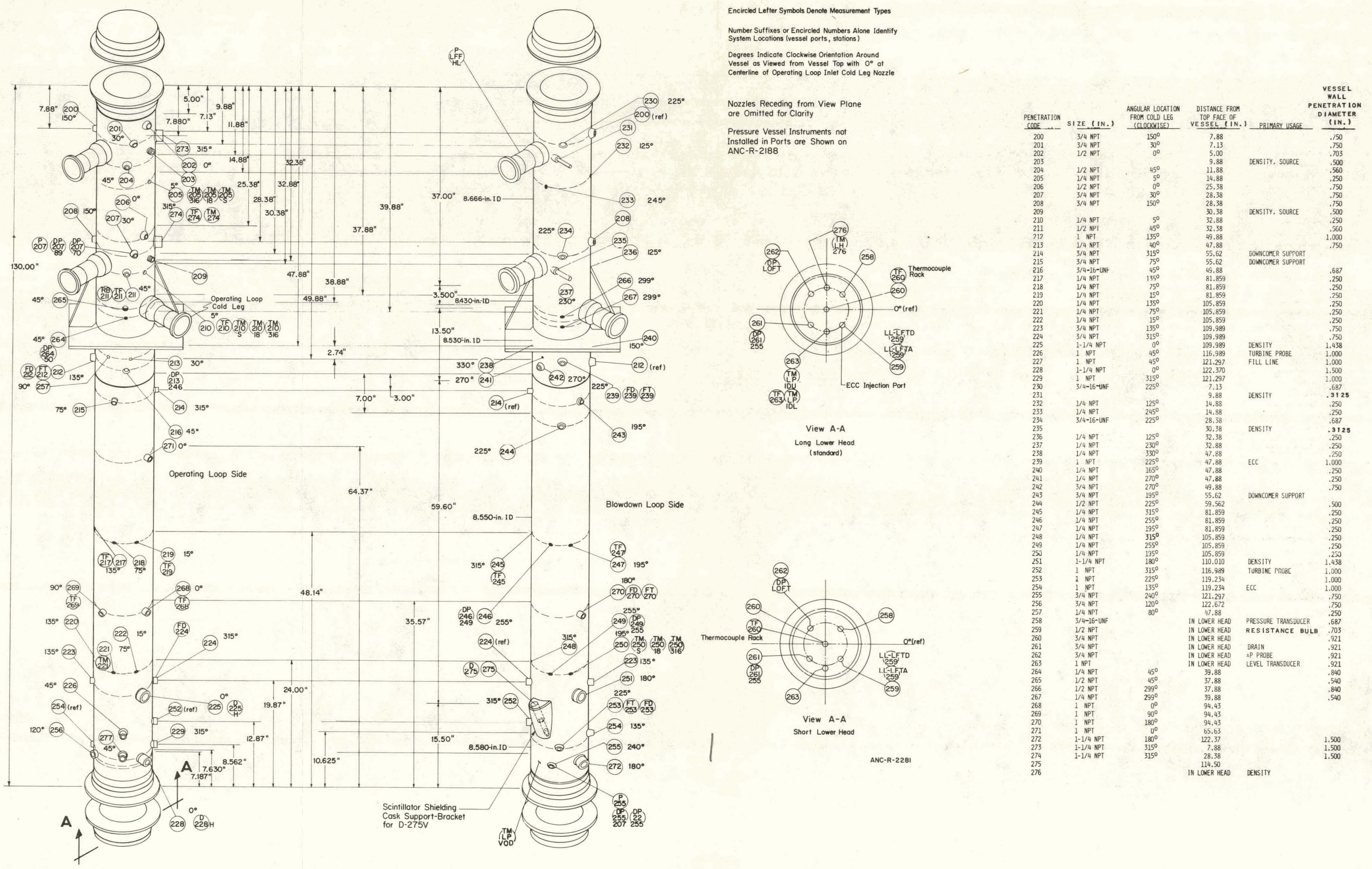

Fig. 12 Pressure vessel with instrumentation -- isometric. 


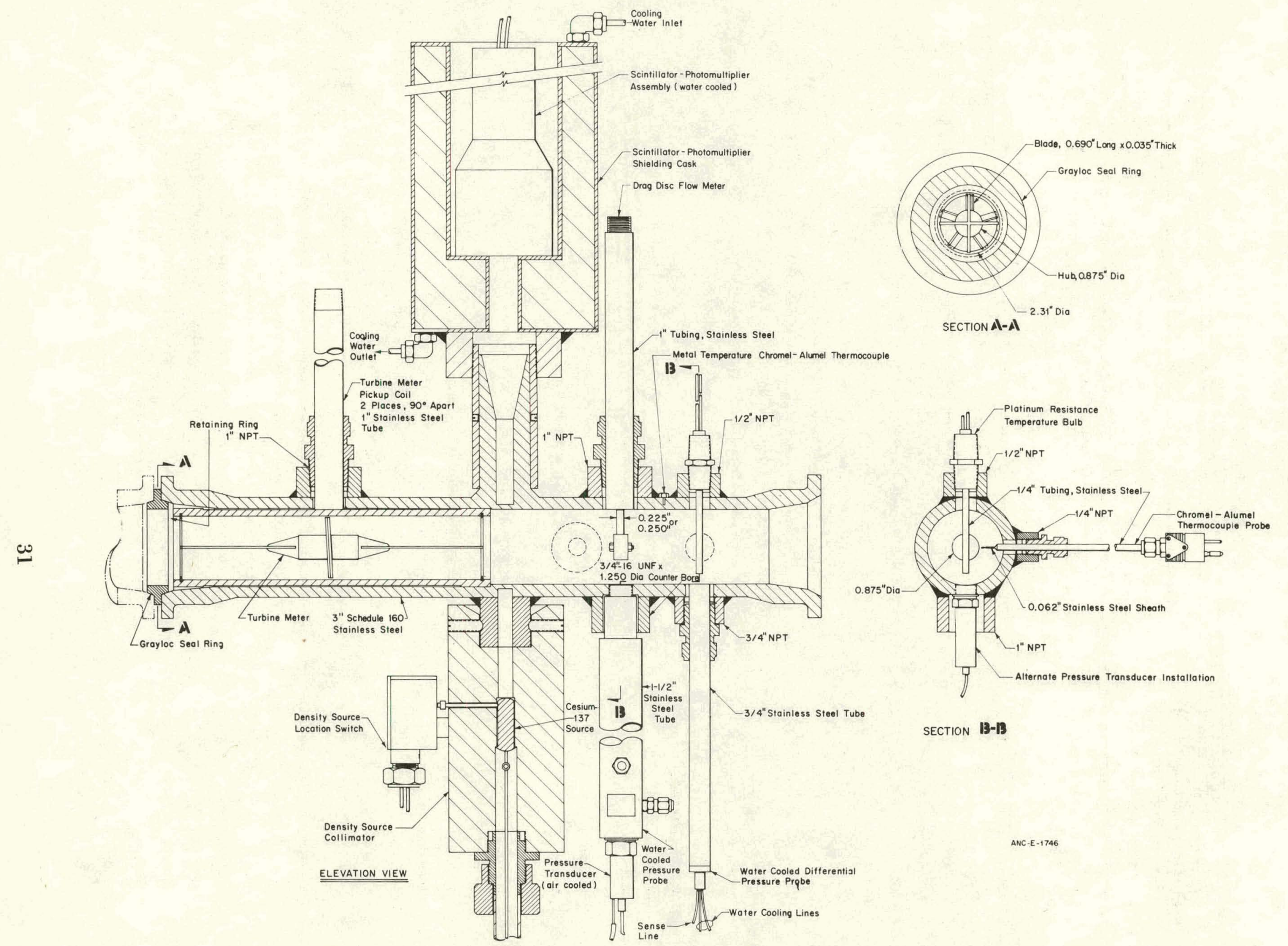

Fig. 13 Typical instrumented spool piece. 
TABLE V

MEASUREMENT LOCATIONS

\begin{tabular}{|c|c|}
\hline Measurement Designation ${ }^{[a]}$ & Location Description [b] \\
\hline \multicolumn{2}{|l|}{ Time of Break (Break Wire) } \\
\hline $\mathrm{BW}-52$ & Blowdown loop cold leg, vessel side \\
\hline BW-62 & Blowdown loop cold leg, simulated pump side \\
\hline \multicolumn{2}{|l|}{ Density, Fluid } \\
\hline $\mathrm{D}-1 \mathrm{~V}$ & Operating loop hot leg, Spool 1 (vertical) \\
\hline $\mathrm{D}-5 \mathrm{~V}$ & Operating loop hot leg, Spool 5 (vertical) \\
\hline$D-15 V$ & Operating loop pump suction, Spool 15 (vertical) \\
\hline$D-19 v$ & Operating loop pump discharge, Spool 19 (vertical) \\
\hline $\mathrm{D}-22 \mathrm{H}$ & Uperating loop cold leg, Sponl 22 (horizontal) \\
\hline$D-22 \mathrm{~V}$ & Operating loop cold leg, Spool.22 (vertical) \\
\hline$D-50 \mathrm{~V}$ & Blowdown loop cold leg, Spool 50 (vertical) \\
\hline D-70v & Blowdown loop hot leg, Spool 70 (vertica1) \\
\hline $\mathrm{D}-76 \mathrm{~V}$ & Blowdown loop, cold leg, Spool 76 (vertical) \\
\hline$D-83 V$ & Pressure suppression header near downcomer (vertical) \\
\hline D-225H & Core barrel inlet, 110.0 inches and $0^{\circ}$ (horizontal) \\
\hline $\mathrm{D}-228 \mathrm{H}$ & Lower plenum, 122.4 inches and $0^{\circ}$ (horizontal) \\
\hline D-275V & Lower plenum (diagonal gamma heam), 114.5 inches, $315^{\circ}$ \\
\hline \multicolumn{2}{|l|}{ Differential Pressure } \\
\hline DP-HN2-61 & Blowdown loop hot leg nozzle downstream throat (Port 2) to Station 61 \\
\hline DP-HN4-61 & $\begin{array}{l}\text { Across hot leg nozzle outlet, downstream nozzle expansion section (Port 4) } \\
\text { to Station } 61\end{array}$ \\
\hline$D P-L O F T$ & Lower plenum to upper plenum of vessel \\
\hline DP-1-5 & Operating loop hot leg, Spool 1 to Spool 5 \\
\hline $\mathrm{DP}-3-5$ & Operating loop hot leg, Spool 3 to Spool 5 \\
\hline $\mathrm{DP}-5-13$ & Operating loop, across steam generator, Spool 5 to Spool 13 \\
\hline DP-8-13 & Operating loop pump suctiun orificc, Spool 8 to Spool 13 \\
\hline $\mathrm{DP}-13-15$ & Operating loop, Spool 13 to Spool 15 \\
\hline DP-19-15 & Operating loop, across pump, Spool 19 to Spool 15 \\
\hline DP-19-15L & Operating loop, across pump, Spool 19 to Spool 15 (low range) \\
\hline DP-19-22 & Operating loop, Spool 19 to Spool 22 \\
\hline $\mathrm{DP}-22-1$ & $\begin{array}{l}\text { Across pressure vessel, operating loop cold leg to hot leg, } \\
\text { Spool } 22 \text { to Spool } 1\end{array}$ \\
\hline$D P-22-255$ & Operating loop cold leg to lower plenum, Spool 22 to Station 255 \\
\hline DP-52-62 & Between rupture discs, inner disc cavities, Spool 52 to Spool 62 \\
\hline $\mathrm{DP}-70-96$ & Blowdown loop, across simulated steam generator, Spool 70 to Spool 96 \\
\hline $\mathrm{DP}-76-61$ & Across blowdown loop hot leg nozzle, Spool 76 to Station 61 \\
\hline DP-76-HN2 & Blowdown loop, Spool 76 to hot leg nozzle downstream throat (Port 2) \\
\hline DP-81-83 & Pressure suppression header to downcomer entrance at header "Y" \\
\hline DP- $81-85$ & $\begin{array}{l}\text { Pressure suppression header to downcomer entrance in pressure suppression } \\
\text { tank }\end{array}$ \\
\hline
\end{tabular}




\section{TABLE V (contd.)}

\section{MEASUREMENT LOCATIONS}

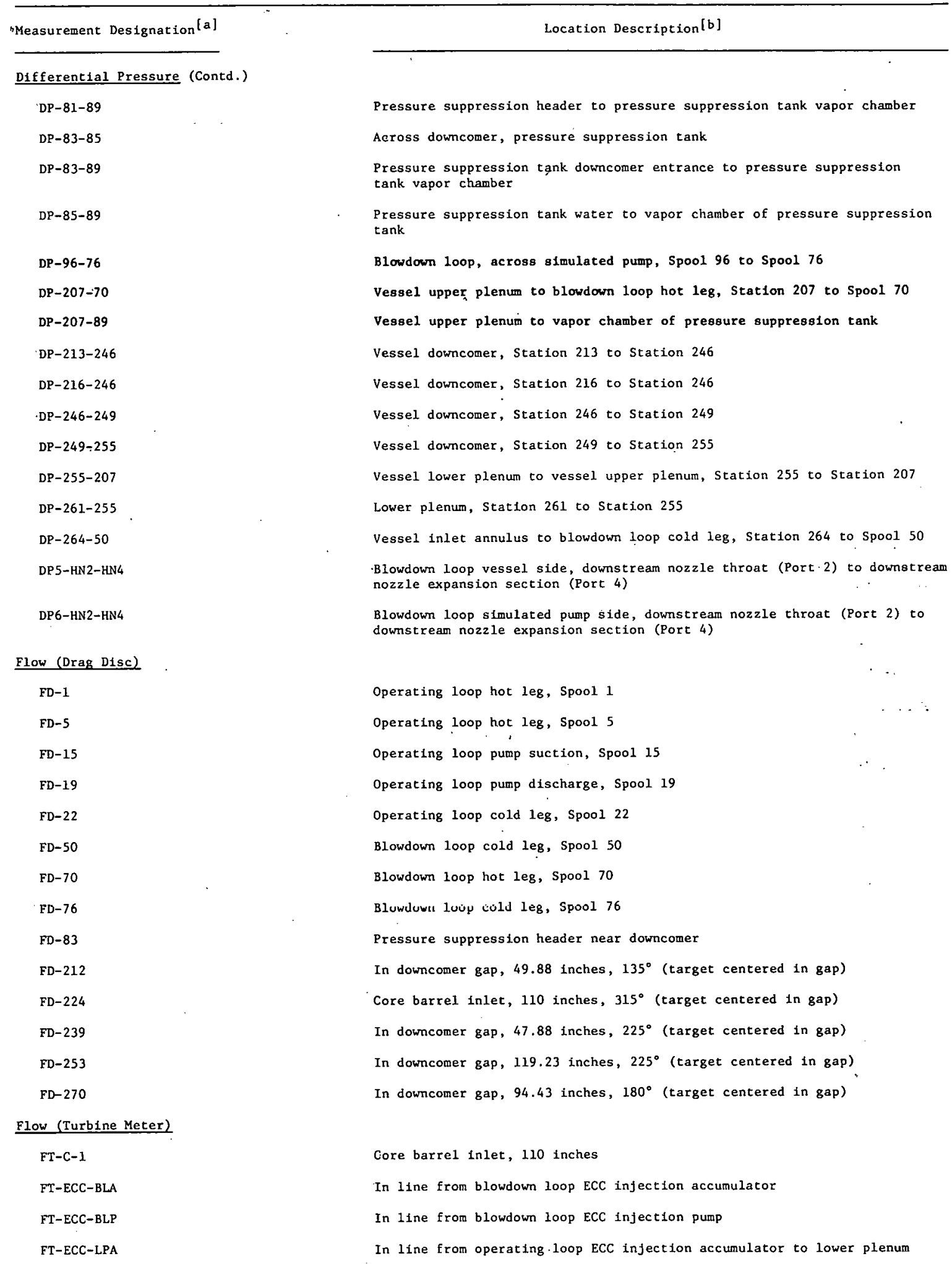


TABLE V (contd.)

MEASUREMENT LOCATIONS

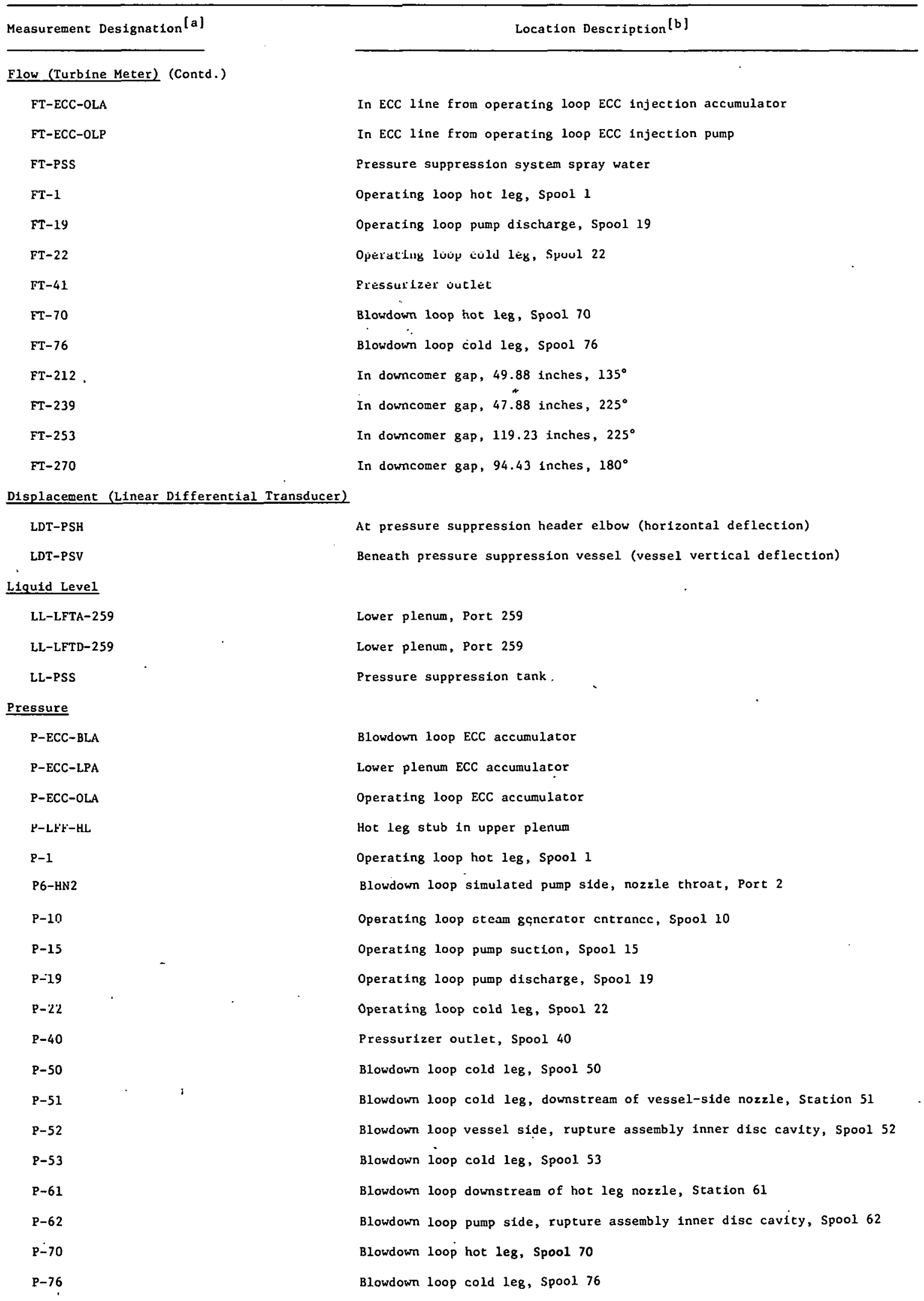


TABLE V (contd.)

MEASUREMENT LOCATIONS

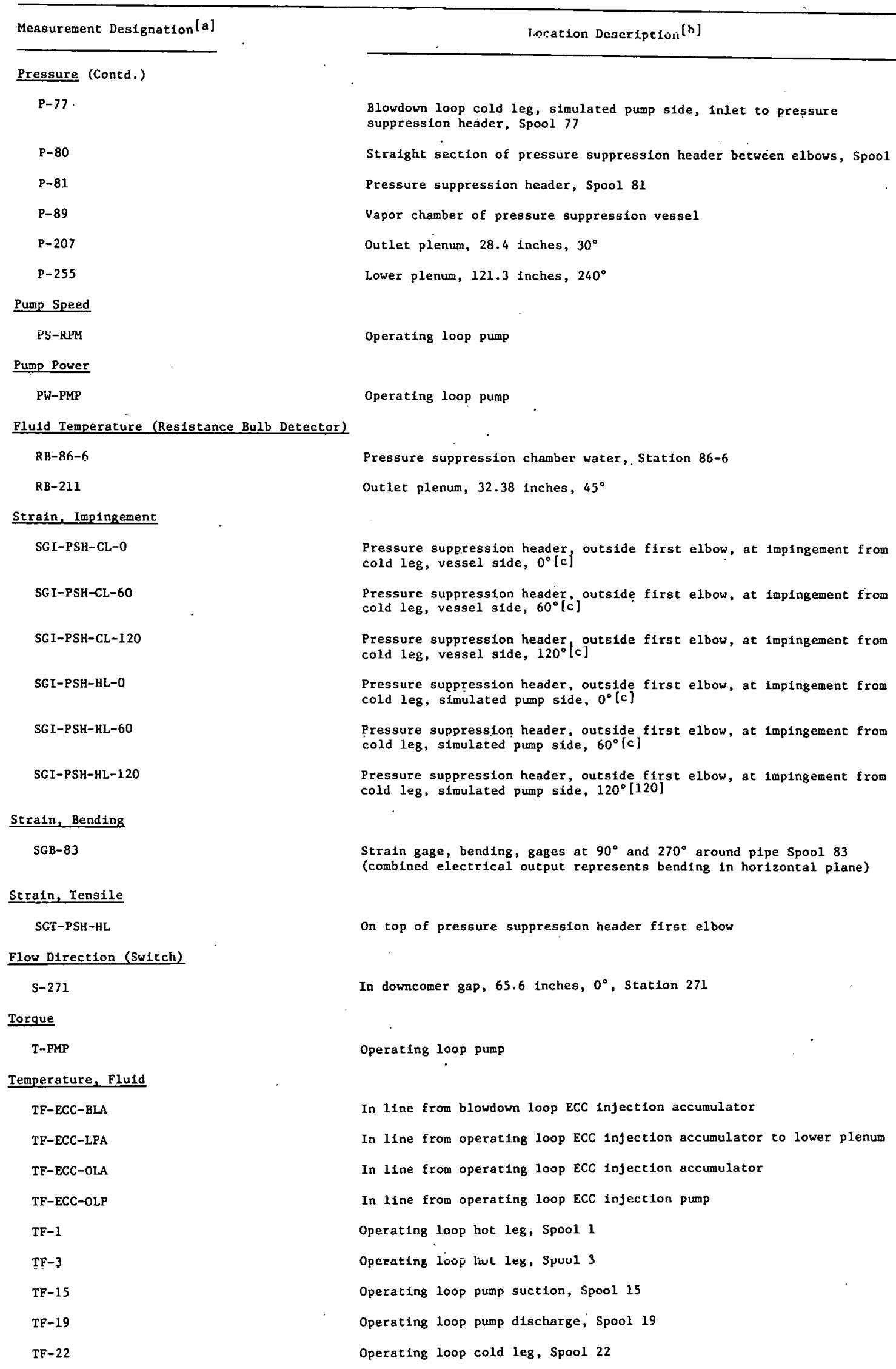


TABLE V (contd.)

MEASUREMENT LOCATIONS

\begin{tabular}{|c|c|c|}
\hline Measurement Desi & signation $[a]$ & Location Descriptionlb] \\
\hline \multicolumn{3}{|c|}{ Temperature, Flu1d (Contd.) } \\
\hline$T E-40$ & & Pressurlzer outlet, Spool 40 \\
\hline$T F-47 D-180$ & & $\begin{array}{l}\text { In downcomer gap, } 248 \text { inches, } 180^{\circ} \text {, excending } 1 / 8 \text { inch into fluid from } \\
\text { vessel wall side }\end{array}$ \\
\hline $\mathrm{TF}-48 \mathrm{C}-0$ & & $\begin{array}{l}\text { In downcomer gap, } 248 \text { inches, } 0^{\circ} \text {, extending } 1 / 8 \text { inch into fluid from } \\
\text { core barrel }\end{array}$ \\
\hline $\mathrm{TF}-48 \mathrm{C}-180$ & & $\begin{array}{l}\text { In downcomer gap, } 448 \text { inches, } 180^{\circ} \text {, extending } 1 / 8 \text { inch into fluid from } \\
\text { l:Ute Ualte1 }\end{array}$ \\
\hline$T F-48 D-0$ & & $\begin{array}{l}\text { In downcomer gap, } 248 \text { inches, } 0^{\circ} \text {, extending } 1 / 8 \text { inch into fluid from } \\
\text { vesse.1 wall side }\end{array}$ \\
\hline$T F-48 D-180$ & & $\begin{array}{l}\text { In downcutier gap, } 48 \text { inchco, } 180^{\circ} \text { uxtending } 1 / 8 \text { inch into fluid from } \\
\text { vessel wall side }\end{array}$ \\
\hline TF-50 & & Blowdown loop cold leg, Spool 50 \\
\hline TF-51 & & Blowdown loop cold leg downstream of vessel-side nozzle \\
\hline $\mathrm{TF}-70$ & & Blowdown loop hot leg, Spool 70 \\
\hline TF-76 & & Blowdown loop cold leg, Spool 76 \\
\hline $\mathrm{TF}-78 \mathrm{D}-0$ & & In downcomer gap, $\sim 78$ inches, $0^{\circ}$ \\
\hline$T F-78 D-180$ & & In downcomer gap, $\sim 78$ inches, $180^{\circ}$ \\
\hline $\mathrm{TF}-83$ & & $\begin{array}{l}\text { Pressure suppression header near downcomer entrance ( } 1 \text { inch from ID of } \\
\text { header on but (unI) }\end{array}$ \\
\hline$T F-86-1$ & & Pressure suppression vessel, Station $86-1$ \\
\hline TF-86-2 & & Pressure suppression vessel, Station $86-2$ \\
\hline TF-86-3 & & Pressure suppression vessel, Station $86-3$ \\
\hline TF-86-4 & & Pressure suppression vesse1, Station $86-4$ \\
\hline TF-86-6 & & Pressure suppression vesse1, Station 86-6 \\
\hline TF-88 & & Pressure suppression vessel vapor chamber, 2 inches from tank wall \\
\hline TF-95D-45 & & In downcomer gap, 2.95 inches, $45^{\circ}$ \\
\hline$T F-9.5 n-22.5$ & & In downcomer gap, 295 Inches, $225^{\circ}$ \\
\hline TF-96 & & Blowdown loop stmulated steam generator discharge, Spool 96 \\
\hline TF -210 & & Outlet plenum, 32.88 Inches, $5^{\circ}$ \\
\hline TF-211 & & Outlet plenum, 32.4 inches, $45^{\circ}$ \\
\hline TF-214 & & In downcomer gap, 55.62 inches, $315^{\circ}$ \\
\hline TF-215 & & In downcomer gap, 55.62 inches, $75^{\circ}$ \\
\hline$\overline{\mathrm{T}} \overline{\mathrm{F}}-217$ & & In downcomer gap, 81.86 inches, $135^{\circ}$ \\
\hline TF-219 & & In downcomer gap, 81.86 inches, $15^{\circ}$ \\
\hline TF-245 & & In downcomer gap, 81.86 inches, $315^{\circ}$ \\
\hline $\mathrm{TF}-247$ & & In downcomer gap, 81.86 inches, $195^{\circ}$ \\
\hline $\mathrm{TF}-260-2$ & . & $\begin{array}{l}\text { Lower plenum, vertical thermocouple rack, 2-Inch level from inside bottor } \\
\text { of lower head }\end{array}$ \\
\hline TF-260-4 & . & $\begin{array}{l}\text { Lower plenum, vertical thermocouple rack, } 4 \text {-inch level from inside bottom } \\
\text { of lower head }\end{array}$ \\
\hline $\mathrm{TF}-260-6$ & & $\begin{array}{l}\text { Lower plenum, vertical thermocouple rack, 6-inch level from inside bottom } \\
\text { of lower head }\end{array}$ \\
\hline TF-260-8 & & $\begin{array}{l}\text { Lower plenum, vertical thermocouple rack, 8-1nch level from inside botrom } \\
\text { of lower head }\end{array}$ \\
\hline TF-260-10 & & $\begin{array}{l}\text { Lower plenum, vertical thermocouple rack, } 10 \text {-inch level from inside bottom } \\
\text { of lower head }\end{array}$ \\
\hline
\end{tabular}


TABLE V (contd.)

'MEASUREMENT LOCATIONS

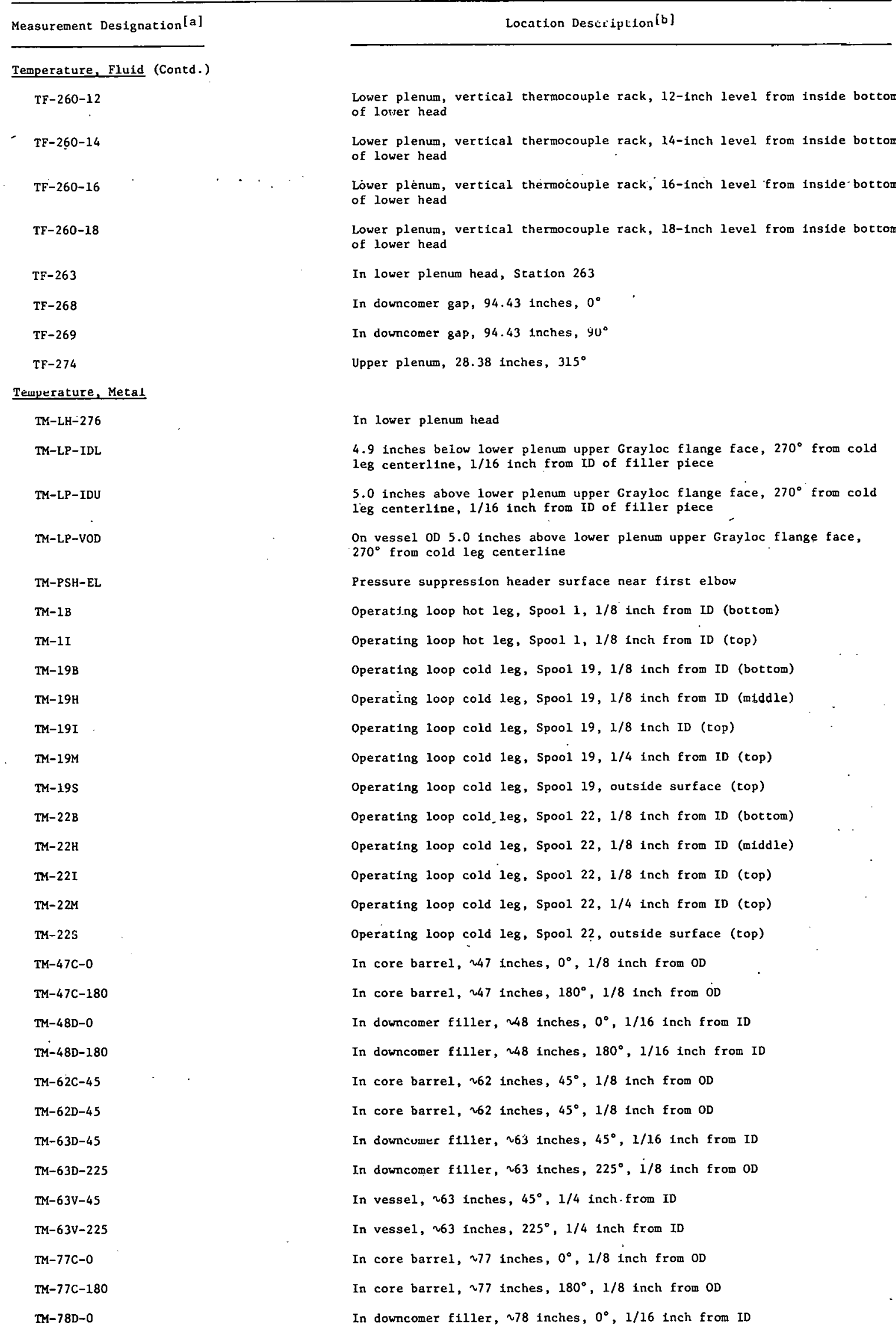




\section{TABLE V (contd.)}

\section{MEASUREMENT LOCATIONS}

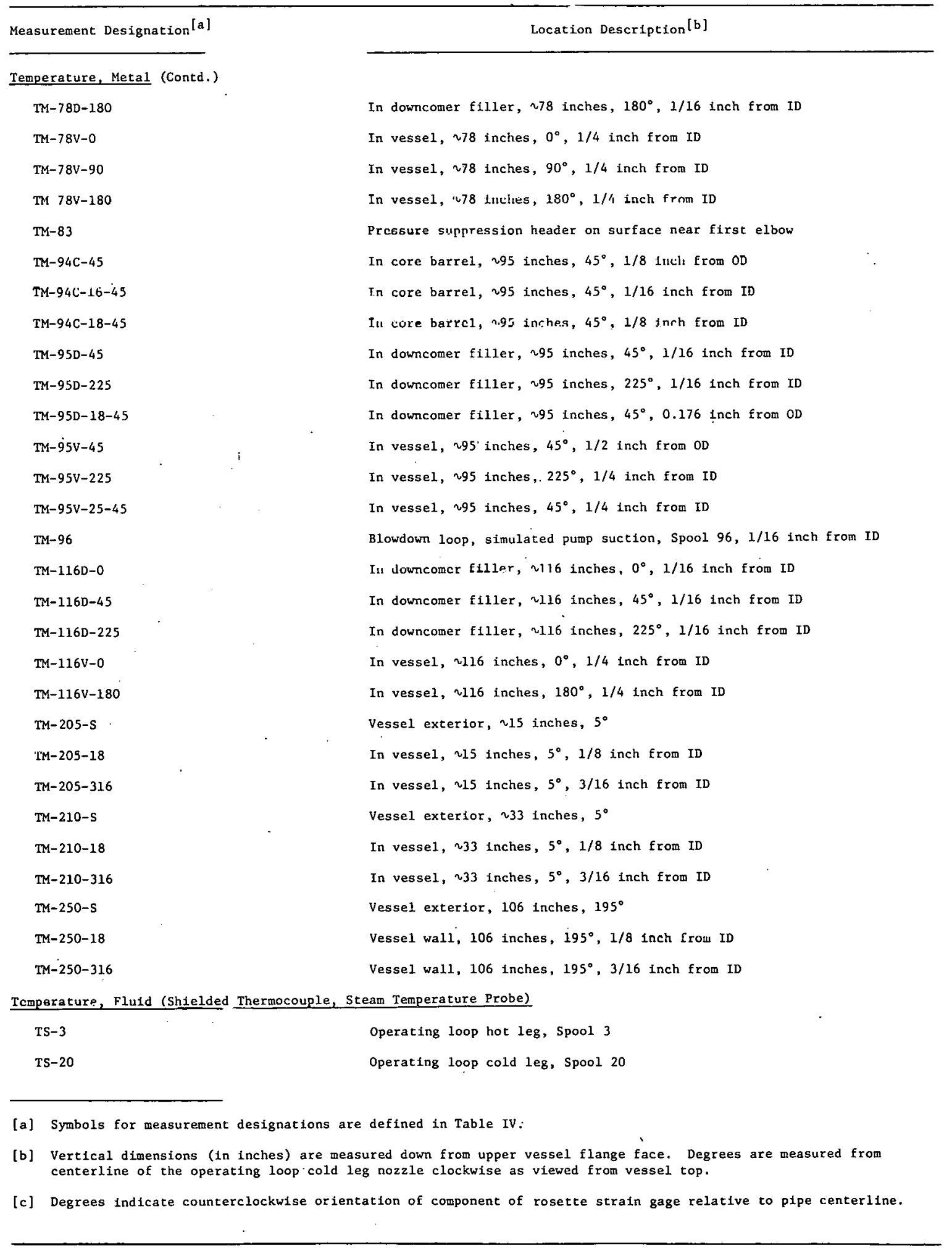




\section{TABLE VI}

\section{DETECTOR CHARACTERISTICS AND MEASUREMENT SYSTEM MAXIMUM ERROR}

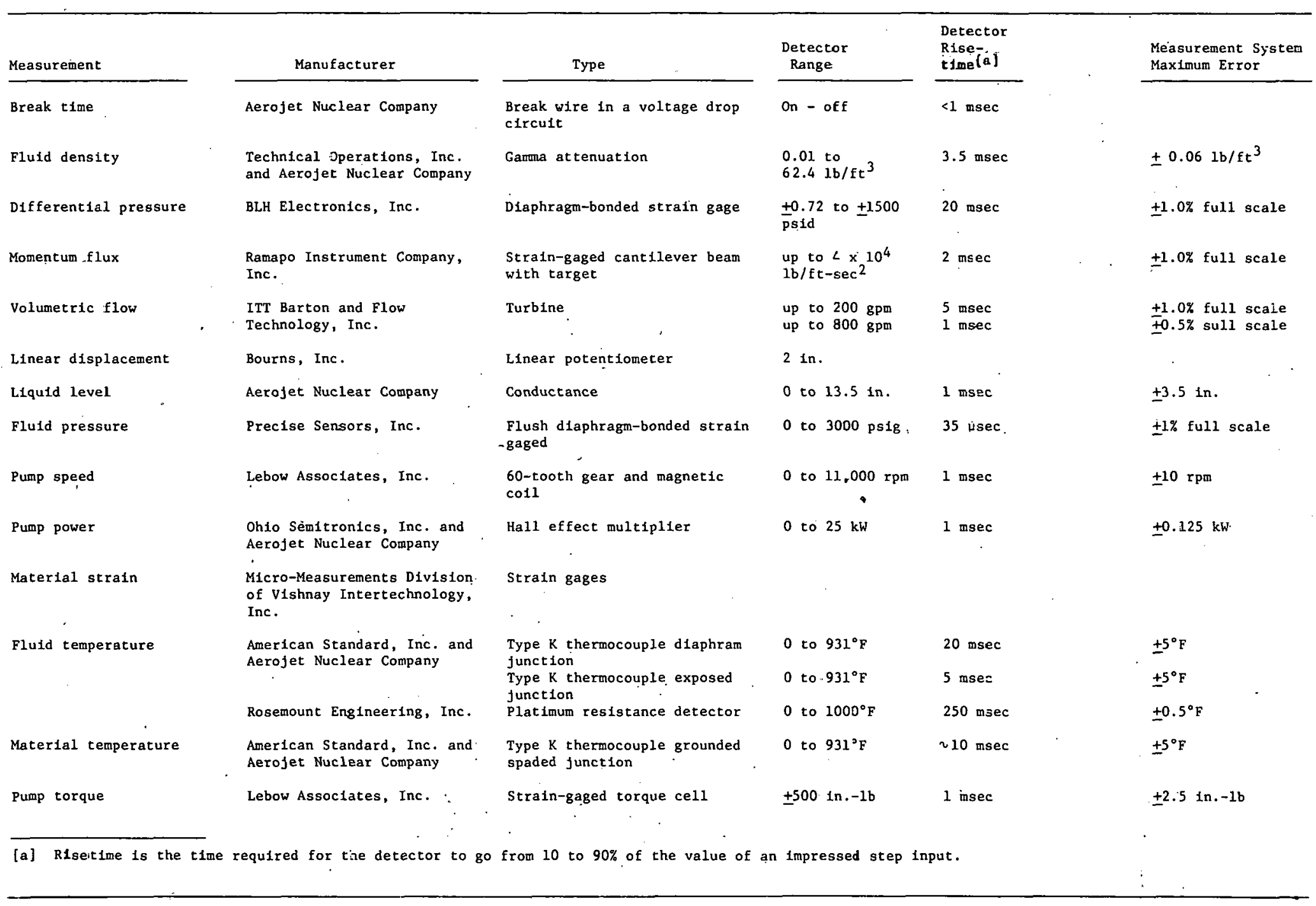




\section{OPERATING PROCEDURES AND TEST CONDITIONS}

For blowdown tests, the primary system is brought to operating temperature by heat additions from the core heaters and pressurizer heaters and by heat introduced into the system by operation of the primary coolant pump. The system is brought to standard operating conditions of about 2250 psig and $575^{\circ} \mathrm{F}$ and then subjected to a double-ended shear (simulated by the rupture disc system). The system is completely depressurized in about 30 seconds and the blowdown test is terminated. The hot-wall tests are initiated shortly after termination of the blowdown tests.

\section{PRIMARY SYSTEM HEATUP AND PRESSURIZATION}

The main source of heat for the primary coolant is the incore heater rods. Nine rods are mounted in a $3 \times 3$ array inside the inner core barrel at the upper end of the core. The active heater rods $(30 \mathrm{~kW}$ each) are connected to two dc power sources to provide a variable heatup capability. Three of the rods are connected to a variable power source of $0-155 \mathrm{Vdc}$ and three are connected to a constant $155-\mathrm{Vdc}$ power source. The three remaining rods are not powered. Heater rod power is turned off before blowdown is initiated.

The pressurizer heaters serve to heat the water in the pressurizer to saturation temperature corresponding to the preset testing pressure. The pressurizer heatup rate is controlled manually to provide the desired pressure increase. When the normal operating system pressure is reached $(2250 \pm 10 \mathrm{psig})$, the heaters are placed in an automatic mode and are controlled by an on-off type pressure switch. The pressurizer liquid level is controlled automatically by a spill and makeup system to maintain a standard water level band. The automatic level control system may be overridden for plant operation when steam is not present in the pressurizer and during steam bubble formation. Pressurizer water level is recorded at blowdown initial conditions. A minimum of four hours is required to achieve blowdown conditions.

\section{TESTING SEQUENCE}

The following sequence of events is performed prior to each test to ensure consistent test initiation throughout the test series.

\section{Test Initiation Sequence}

(a) Primary coolant water sample obtained for water chemistry determination

(b) Tapes started 
(c) 120-second countdown started

(d) $T$ minus 60 seconds, bypass line block valve closed and verified closed

(e) T minus 20 seconds, pump low pressure trip bypassed

(f) T minus 10 seconds, vessel heaters turned off and system pressure recorded

(g) T minus 5 seconds, pressure suppression tank circulating pump turned off

(h) T minus 2 seconds, system makeup pump turned off

(i) $\mathrm{T}$ minus 0 seconds, rupture discs fired, pressurizer heater off, system pressure recorded. 


\title{
VI. METHODS USED TO OBTAIN TEST DATA FROM
}

\author{
INSTRUMENT OUTPUT
}

The data, in many cases, are adjusted to account for instrument drift, changes in gain, detector pressure sensitivity, and detector thermal sensitivity. The following paragraphs explain the methods used to obtain and normalize the test data.

An instrumentation system calibration with a known input source is made prior to each isothermal test. Data from the calibration are reduced to obtain an average output for each channel. The average output is compared with the known calibration iniput such that a gain correction is obtained and applied by computer program to the test data.

\section{PRESSURE}

Pressure measurements are obtained by calibrated pressure transducers. With the isothermal system at steady state pretest conditions (about 2250 psig and $575^{\circ} \mathrm{F}$ ) each pressure transducer output is normalized to agree with the pretest pressure obtained from a precision pressure gage located on the vessel head. The total change measured for each transducer as the system pressure drops from the presaturation pressure to the postsaturation pressure, as recorded from the precision pressure gage, is obtained by applying a modified calibration factor to obtain the required total pressure change.

\section{DIFFERENTIAL PRESSURE}

The differential pressure measurements are made with calibrated differential pressure transducers. To compensate for the pressure sensitivity of the transducer, the voltage output as a function of pressure is recorded for each detector during pretest hydrostatic operation at zero flow conditions. The resulting correction curve is applied to the recorded test data through use of a computer program.

\section{TEMPERATURE}

Temperature measurements are made with thermocouples and variable resistance devices. The fluid temperature data are normalized by assigning the pretest temperature to those detectors that deviate more than $\pm 3^{\circ} \mathrm{F}$ from the pretest temperature. The pretest material temperature data are normalized by the same method only if the detector output is greater than the fluid temperature. 


\section{DENSITY}

Fluid density data for semiscale tests are obtained by a gamma-attenuation technique that provides a measurement of the average fluid density across the section being monitored. A gamma source is placed on one side of the section and a gamma detector is placed on the opposite side. The gamma beam is collimated and passed through reliefs in the pressure boundary and through the fluid to the photoscintillation detector. The output from the scintillation detector is amplified and recorded in volts, and is processed using a computer data conversion program based on a derived calibration factor and on the calculated initial fluid density.

\section{VOLUMETRIC FLOW RATE}

Volumetric flow rate measurements are made with turbine flowmeters through which all fluid within a given flow channel passes. The digital signal from the flowmeter is converted directly to volumetric flow rate through use of calibration data obtained from the manufacturer and verified by Aerojet Nuclear Company.

\section{VELOCITY}

Velocity measurements are made with small turbine flowmeter probes inserted into the flow stream. These probes operate in a manner similar to that of conventional turbine flowmeters except that only a fraction of the fluid within a given flow passage passes through them. The digital signal from the probe is converted directly to velocity through use of calibration data obtained from the manufacturer and verified by Aerojet Nuclear Company.

\section{MOMENTUM FLUX}

Momentum flux measurements are made with drag disc devices. These devices are basically strain-gaged cantilever beams with an enlarged area on one end which protrudes into a flowing fluid. The analog output is proportional to fluid density times fluid velocity

squared $\left(\rho \mathrm{v}^{2}\right)$. On the basis of the initial fluid density and the calibration curve, the initial voltage from the instrument is assigned a value commensurate with initial pretest steady state flow conditions. To compensate for the thermal sensitivity of the device, the voltage output as a function of temperature is recorded during pretest warmup at zero-flow conditions. The resulting correction curve, plus the hysteresis condition and the instrument calibration curve, is applied to the recorded test data through use of a computer data conversion program. 


\section{MASS FLOW RATE}

Mass flow rate is not measured directly but is computed from any two of the three directly measured quantities: density, volumetric flow rate, and momentum flux. The mass flow rates within the system during the blowdown transient are calculated with a digital computer from either

$$
m=\left[\rho\left(\rho v^{2}\right) A^{2}\right]^{1 / 2}
$$

or

$$
\mathrm{m}=\rho \mathrm{vA}
$$

where

$$
\begin{aligned}
& \mathrm{m}=\text { fluid flow rate }(\mathrm{lb} / \mathrm{sec}) \\
& \rho \quad=\text { measured density }\left(\mathrm{lb} / \mathrm{ft}^{3}\right) \\
& \rho \mathrm{v}^{2} \stackrel{=}{=} \text { measured momentum flux }\left(\mathrm{lb} / \mathrm{sec}^{2}-\mathrm{ft}\right) \\
& \mathrm{v}=\text { velocity }(\mathrm{ft} / \mathrm{sec}) \\
& \mathrm{A}=\text { cross-sectional flow area }\left(\mathrm{ft}^{2}\right) .
\end{aligned}
$$




\section{REFERENCE}

1. D. J. Olson, Semiscale Blowdown and Emergency Core Cooling (ECC) Project Test Report - Tests 848, 849, and 850 (ECC Injection), ANCR-1036 (June 1972). 
